Article

\title{
Supervising System Stress in Multiple Markets
}

\author{
Mikhail V. Oet ${ }^{1,2, *}$, John M. Dooley ${ }^{3}$, Amanda C. Janosko ${ }^{3}$, \\ Dieter Gramlich ${ }^{4}$ and Stephen J. Ong 5
}

1 Economist, Supervision and Regulation, Federal Reserve Bank of Cleveland, 1455 E 6th St, Cleveland, OH 44114, USA

2 Nonprofit Research Fellow, Case Western Reserve University, 10900 Euclid Ave, Cleveland, OH 44106, USA

3 Economic Analyst, Supervision and Regulation, Federal Reserve Bank of Cleveland, 1455 E 6th St, Cleveland, OH 44114, USA;

E-Mails: john.m.dooley@clev.frb.org (J.M.D.); amanda.c.janosko@clev.frb.org (A.C.J.)

4 Professor of Banking, Baden-Wuerttemberg Cooperative State University, Heidenheim 89518, Germany; E-Mail: gramlich@dhbw-heidenheim.de

5 Vice President, Supervision and Regulation, Federal Reserve Bank of Cleveland, 1455 E 6th St, Cleveland, OH 44114, USA; E-Mail: stephen.j.ong@clev.frb.org

* Author to whom correspondence should be addressed; E-Mail: mikhail.v.oet@clev.frb.org; Tel.: +1-216-774-2684; Fax: +1-216-579-2932.

Academic Editors: Andrea Consiglio and Stavros A. Zenios

Received: 9 April 2015 / Accepted: 1 September 2015 / Published: 14 September 2015

\begin{abstract}
This paper develops an extended financial stress measure that considers the supervisory objective of identifying risks to the stability of the financial system. The measure provides a continuous and bounded signal of financial stress using daily public market data. Broad coverage of material financial system markets over time is achieved by leveraging dynamic credit weights. We consider how this measure can be used to monitor, analyze, and alert financial system stress.
\end{abstract}

Keywords: financial stress; supervision; financial system stability; systemic risk 


\section{Introduction}

A major hurdle for supervisors is the lack of transparency surrounding the financial system which can exacerbate [1-3] stress and its factors. The lack of transparency makes it difficult to recognize a building perilous episode. In turn; this hinders risk management by market participants and challenges the design of efficient crisis management strategies by regulatory agencies. A measurement tool which supports the ability to continuously identify and analyze financial system conditions would alleviate the information obstacle faced by supervisors - those critically watching financial markets. ${ }^{1}$

Recent research contributions [4-11] to financial stress measurement show a range of supervisory motivations in a common pursuit of a financial stress index (FSI) as a measure of the financial system's state. For example, Hatzius et al. [4] and Brave and Butters [5] attempt to monitor and forecast economic activity while differentiating financial stress from cyclical economic activity. Hakkio and Keeton [6] seek a single measure of financial stress to guide monetary policy. Carlson et al. seek an index construction that indicates "the degree to which conditions in financial markets are similar to periods when policymakers were concerned enough about systemic risks to intervene" [7] (p.2). As a group, this research mostly focuses on quantitative techniques of combining manifest data rather than on the supervisory objective of comprehensive identification of emergent risks to the stability of the financial system. The research of Holló et al. stands out by explicitly addressing the underlying financial system architecture and designing a stress measure "that aims to measure the current state of instability in the financial system as a whole" [8] (p. 8). They achieve this by measuring the current states of instability in different segments of the financial system and condense these states into a single statistic for overall financial stress.

This study aims to contribute to the supervision of financial system stress by making two primary contributions to the literature. First, we enhance the quality of financial stress measurement for supervisory analysis by constructing a measure that enables a more complete picture of financial system stress. This is accomplished by focusing stress measurement on system composition and inclusion of a more comprehensive set of relevant financial markets (Section 2). Second, we demonstrate how the principal supervisory goals of monitoring, analysis, and alerting of conditions within multiple markets can be implemented for our measure (Section 3). Here, we explore the ability of our financial stress measure to monitor the state of financial markets in a manner that reduces the influence of idiosyncratic noise and facilitates the interpretation of systemic stress observations. We then investigate the measure's facility to enhance coincident and retrospective analysis focusing on the sources of financial stress. Specifically, we show how our stress measure can be leveraged to gain useful insights for the U.S. financial system. Finally, we consider how the stress measure may provide alerts of adverse systemic stress developments.

1 In the context of this paper, we find it useful to discuss financial supervision as a common function of diverse participants who engage in critical observation of financial markets. 


\section{Financial Stress Measure for System Supervision}

\subsection{Index Concept and Measurement Criteria}

The construction of a stress measure builds on a definition of financial stress, and a set of architectural principles (i.e., a set of theoretical rules to identify and link the index components consistently). We start with the broad premise that an FSI as a measure of financial stress assesses the latent level of pressure in a financial system. ${ }^{2}$ Systemic financial stress has also been interpreted as measure of excitation in a financial system [12], a measure of imbalance between demand and supply of financial goods [11,13], or as a measure of deviations from long term trends (pressure) in the markets [14].

The financial system is considered to consist of financial intermediaries and financial markets $[15,16]$. Financial intermediaries involve commercial and investment banks as well as different types of financial service institutions, particularly investment funds, securitization vehicles, and finance companies. In representing the U.S. financial markets, the FSI described in this paper extends previous literature which measure system stress through observations in four markets (funding, foreign exchange, credit, equity) by relevant observations from two additional markets (real estate and securitization). In addition, we extend the coverage depth in the foreign exchange and equity markets by inclusion of country and sector variables. Figure 1 displays the conceptual design of the index.

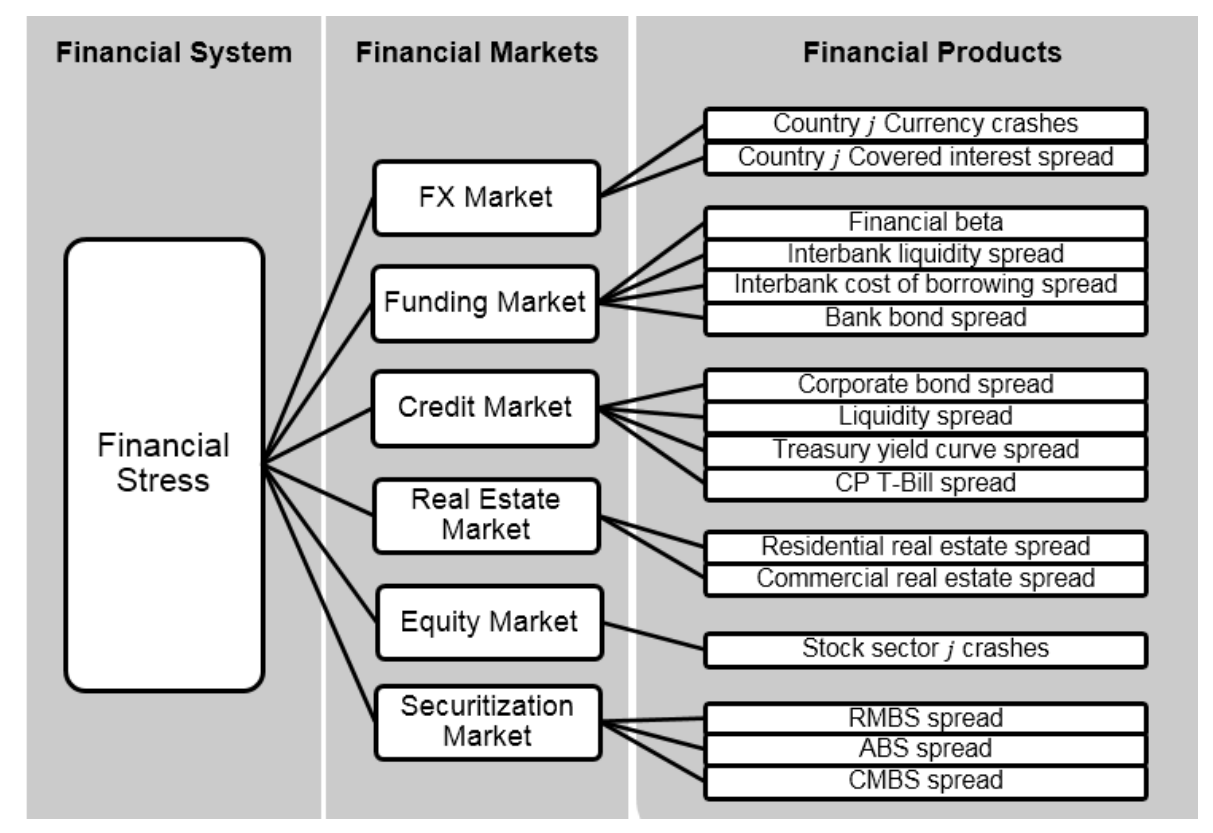

Figure 1. Conceptual model of financial system stress.

Accordingly, the necessary construction elements for the index include the financial system's markets, the observations that describe markets' activities, the transformation of the different types of observations to a common measurement scale, and the aggregation of these variables. While representing an aggregation of variables and weights, the FSI has to remain transparent and modular, thus allowing supervisors to retrace the drivers of systemic stress (see [17]).

2 Financial systems are analyzed in [18-20]. 
We propose that the quality of a financial stress measure can be evaluated by comparing it against an independent benchmark of financial system disturbances ${ }^{3}$ using heuristic information criteria. To determine the quality of information provided by coincident measures of systemic conditions, Oet et al. [21] consider a combination set of metrics of association between a candidate measure and the benchmark, including Type I error rate, Type II error rate, information value (IV), noise to signal (NTSR), and relative usefulness $\left(U_{R}(\mu)\right)$. Applying this empirical evidence, we suggest that the acceptance criteria for a candidate stress measure include the following information quality metrics: (1) noise to signal ratio less than 0.3 (a ratio less than 1 implies a beneficial measure), (2) information value between 0.3 and 0.6 (Siddiqi [22] describes 0.3 to 0.5 as a strong), and (3) relative usefulness of at least $0.3 .{ }^{4}$ Taken individually, the information criteria may not appear burdensome to meet. However, taken collectively, they limit the ability to game the Type I and Type II error rates (to achieve a low NTSR), require a focus on consistent association across the entire series (through $I V$ ), and consider the relative cost $\mu$ to supervisors of not implementing policy when a crisis occurs (through $U_{R}(\mu)$ ).

\subsection{Variable Selection and Data}

Our FSI is constructed as a continuous stress variable, using relative difference (spreads and spread-like) measures. We assume that increased uncertainty in a market will be perceived by indicators based upon spreads as a distortion of the connection between two fundamentally related series. We propose that reasonable measures of stress in the funding market include spreads capturing pressures on financial institutions' direct funding (bonds), and indirect financing (interbank activity and liquidity) which affect liquidity and interest rate risk. In the credit market, financial institutions act as intermediaries for short and long-term borrowing. Thus, measures of stress in the credit market include spreads capturing pressures on corporate bonds, commercial papers, and treasury yield curve, as well as treasuries' liquidity (bid-ask).

In the equity market, it is reasonable to include observable measures that describe the extent to which equities have collapsed over the previous year in various industry groups following [23]. We consider a ten sector partition of the S\&P 500 to facilitate interpretation of observed stress. In the foreign exchange market, observable measures of flight from the U.S. dollar toward foreign currencies are included. In addition, the relative stress on U.S. vs. international credit markets may be observed through deviations from interest rate parity. We calculate currency crashes and covered interest spreads for seven of the G20 economies with floating exchange rates and large trade balances with the U.S.

3 This generalizes the ad hoc alternatives of crisis lists and expert surveys.

4 Section 2.4 summarizes the benchmark construction (for full details see [21]). 
Table 1. Financial stress index construction.

\begin{tabular}{|c|c|c|c|c|}
\hline $\begin{array}{c}\text { Financial } \\
\text { Market }\end{array}$ & Financial Product & Calculation & Indicator Notes & Weight Notes \\
\hline \multirow{4}{*}{$\begin{array}{l}\text { Funding } \\
\text { Market }\end{array}$} & Financial Beta (FB) & $\operatorname{cov}\left(\left.r_{t}\right|_{t-1} ^{t},\left.m_{t}\right|_{t-1} ^{t}\right) / \operatorname{var}\left(\left.m_{t}\right|_{t-1} ^{t}\right)$ & $\begin{array}{l}\text { Rolling one year covariance between banking sector share prices } \\
\text { (SPTRFINL }^{\mathrm{B}} \text { ) and the S\&P } 500\left(\text { SPXT }^{\mathrm{B}}\right)\end{array}$ & \multirow{4}{*}{ 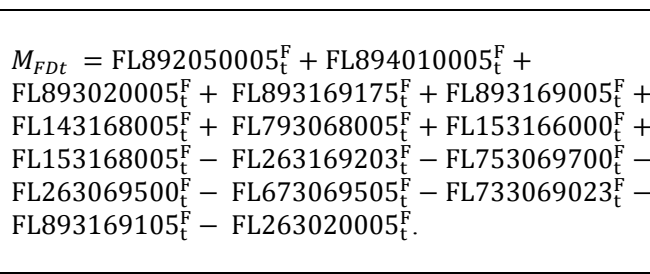 } \\
\hline & Bank Bond Spread (BBS) & $10 A_{t}-10 T B_{t}$ & $\begin{array}{l}\text { Spread between the } 10 \text { year A rated bank bond yields }\left(\mathrm{C} 07010 \mathrm{Y}^{\mathrm{B}}\right) \text { and } \\
\text { the } 10 \text { year treasury constant maturity yields }\left(\mathrm{H} 15 \mathrm{~T} 10 \mathrm{Y}^{\mathrm{B}}\right)\end{array}$ & \\
\hline & Interbank Liquidity Spread (ILS) & $3 m o L_{t}-3 m o T B_{t}$ & $\begin{array}{l}\text { Spread between } 3 \text { month LIBOR (US0003 } \mathrm{M}^{\mathrm{B}} \text { ) and } 3 \text { month treasury } \\
\text { bill secondary market rate }\left(\mathrm{TBSM} 3 \mathrm{M}^{\mathrm{B}}\right)\end{array}$ & \\
\hline & $\begin{array}{l}\text { Interbank Cost of Borrowing } \\
\text { Spread (ICOB) }\end{array}$ & $3 m o L_{t}-F F R_{t}$ & $\begin{array}{l}\text { Spread between the } 3 \text { month LIBOR (US0003M }{ }^{\mathrm{B}} \text { ) and the federal } \\
\text { funds target rate }\left(\text { FDTR }^{\mathrm{B}}\right)\end{array}$ & \\
\hline \multirow{4}{*}{ Credit Market } & Corporate Bond Spread (CBS) & $10 C B_{t}-10 T B_{t}$ & $\begin{array}{l}\text { Spread between the } 10 \text { year Moody's Aaa rated corporate bond yield } \\
\left(\text { MOODCAAA }^{\mathrm{B}}\right) \text { and the } 10 \text { year treasury yield }\left(\mathrm{H} 15 \mathrm{~T} 10 \mathrm{Y}^{\mathrm{B}}\right)\end{array}$ & \multirow{4}{*}{ 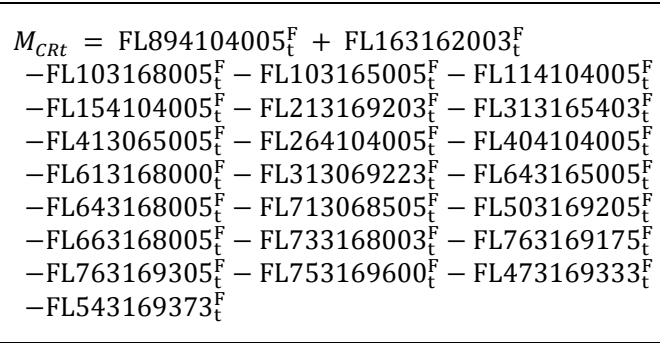 } \\
\hline & $\begin{array}{l}\text { Commercial Paper T-Bill Spread } \\
\text { (CPTBS) }\end{array}$ & $\left(90\right.$ day $\left.C P_{t}\right)-\left(3 m o T B_{t}\right)$ & 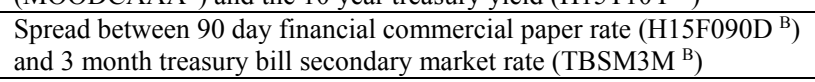 & \\
\hline & Liquidity Spread (LS) & $\left(\frac{1}{30}\right) \sum_{i=0}^{29}\left[\frac{A P_{t-i}-B P_{t-i}}{\left(\frac{A P_{t-i}+B P_{t-i}}{2}\right)}\right]$ & $\begin{array}{l}\text { Thirty trading day moving average of the relative bid-ask price spread } \\
\text { on } 3 \text { month Eurodollar deposits (ECUSD3M }{ }^{\mathrm{D}} \text { ) }\end{array}$ & \\
\hline & $\begin{array}{l}\text { Treasury Yield Curve Spread } \\
\text { (TYCS) }\end{array}$ & $\left(\frac{1}{30}\right) \sum_{i=0}^{29}\left(10 y r_{t-i}-3 m o_{t-i}\right)$ & $\begin{array}{l}\text { Thirty trading day moving average of the difference between } 3 \text { month } \\
\text { treasury bill secondary market rate }\left(\mathrm{TBSM} 3 \mathrm{M}^{\mathrm{B}}\right) \text { on a bond equivalent } \\
\text { basis with } 10 \text { year treasury constant maturity yields }\left(\mathrm{H} 15 \mathrm{~T} 10 \mathrm{Y}^{\mathrm{B}}\right)\end{array}$ & \\
\hline $\begin{array}{l}\text { Equity } \\
\text { Market }\end{array}$ & Stock Market Crashes (SMC) & $\frac{x_{t}}{\max \left[x \in\left(x_{t-j} \mid j=0,1, \ldots, 364\right]\right.}$ & 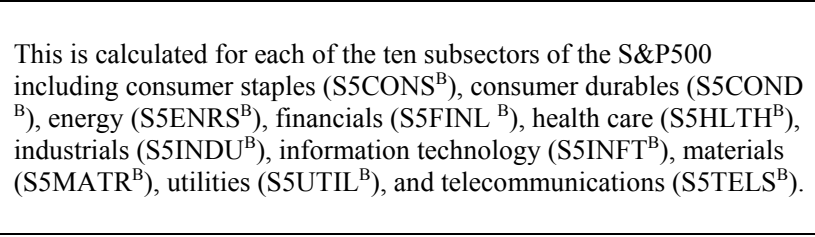 & 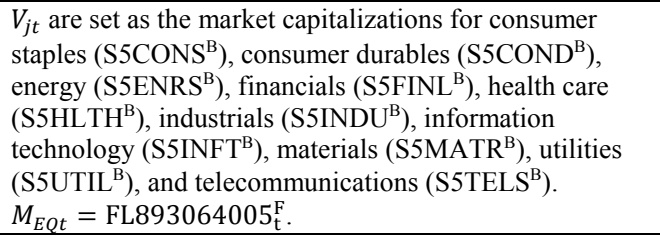 \\
\hline \multirow[b]{2}{*}{$\begin{array}{l}\text { Real Estate } \\
\text { Market }\end{array}$} & $\begin{array}{l}\text { Commercial Real Estate Spread } \\
\text { (CRE) }\end{array}$ & $C R E R_{t}-3 T B_{t}$ & $\begin{array}{l}\text { Spread between realized annual return over the past } 3 \text { years based on a } \\
\text { commercial property index (USNPIRN_R } R^{\mathrm{D}} \text { ) and the } 3 \text { year treasury } \\
\text { note yield (FRTCM } 3 \mathrm{Y}^{\mathrm{D}} \text { ) covering that period. }\end{array}$ & \multirow{2}{*}{ 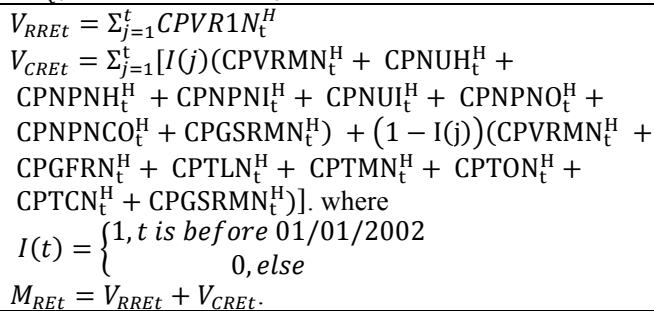 } \\
\hline & $\begin{array}{l}\text { Residential Real Estate Spread } \\
\text { (RRE) }\end{array}$ & $R R E R_{t}-3 T B_{t}$ & 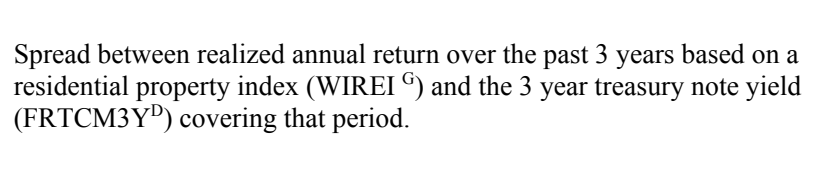 & \\
\hline \multirow{2}{*}{$\begin{array}{l}\text { Securitization } \\
\text { Market }\end{array}$} & ABS Spread (ABS) & $A B S_{t}-5 T B_{t}$ & $\begin{array}{l}\text { Spread between the asset backed bond yield }\left(\mathrm{SYCAAB}^{\mathrm{H}}\right) \text { and the yield } \\
\text { on a } 5 \text { year treasury note }\left(\mathrm{H} 15 \mathrm{~T}^{\mathrm{B}} \mathrm{Y}^{\mathrm{B}}\right)\end{array}$ & \multirow{2}{*}{$\begin{array}{l}\text { The volumes within securitization are taken from SIFMA } \\
V_{\text {ABSt }} \text { is the value of all U.S. asset backed securities } \\
\text { outstanding from the "US ABS Issuance and } \\
\text { Outstanding" file. }\end{array}$} \\
\hline & Commercial MBS Spread (CMBS) & $C M B S_{t}-10 T B_{t}$ & 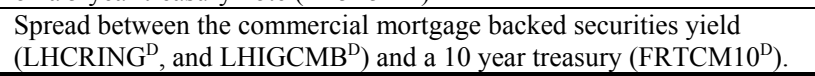 & \\
\hline
\end{tabular}

5 We use the "US ABS Issuance and Outstanding" and "US Mortgage-Related Issuance and Outstanding" worksheets provided by SIFMA [24]. 
Table 1. Cont

\begin{tabular}{|c|c|c|c|c|}
\hline $\begin{array}{c}\text { Financial } \\
\text { Market }\end{array}$ & Financial Product & Calculation & Indicator Notes & Weight Notes \\
\hline $\begin{array}{l}\text { Securitization } \\
\text { Market }\end{array}$ & Residential MBS Spread (RMBS) & $R M B S_{t}-7 T B_{t}$ & $\begin{array}{l}\text { Spread between the yield on agency residential mortgage backed } \\
\text { securities }\left(\text { LHGNM } 30^{\mathrm{B}} \text { ) and the yield of a } 7 \text { year treasury note }\right. \\
\left(\text { FRTCM } 7 \mathrm{Y}^{\mathrm{D}}\right)\end{array}$ & $\begin{array}{l}V_{C M B S t} \text { and } V_{R M B S t} \text { are the values of all U.S. mortgage- } \\
\text { related securities outstanding from the "US Mortgage- } \\
\text { Related Issuance and Outstanding" file ("US Agency } \\
\text { MBS Outstanding" and "NonAgency Outstanding" } \\
\text { worksheets). } M_{S E t}=V_{A B S t}+V_{R M B S t}+V_{C M B S t} \text {. }\end{array}$ \\
\hline \multirow{2}{*}{$\begin{array}{l}\text { Foreign } \\
\text { Exchange } \\
\text { Market }\end{array}$} & Currency Crashes (CC) & $\frac{S_{t}}{\max \left[S_{t} \in\left\{S_{t-j} \mid j=0,1, \ldots, 365\right\}\right]}$ & $\begin{array}{l}\text { We let } \mathrm{S} \text { be the exchange rate between the U.S. dollar and a foreign } \\
\text { currency. The exchange rate is quoted such that it measures the price of } \\
\text { one foreign currency in USD. This calculation is performed for: } \\
\text { Australia }\left(\text { AUDUSD }^{\mathrm{B}}\right) \text {, Canada }\left(\mathrm{CADUSD}^{\mathrm{B}}\right) \text {, the European Union } \\
\left(\text { EURUSD }^{\mathrm{B}}\right) \text {, Great Britain }\left(\mathrm{GBPUSD}^{\mathrm{B}}\right) \text {, Japan }\left(\text { JPYUSD }^{\mathrm{B}}\right) \text {, Mexico } \\
\left(\text { MXNUSD }^{\mathrm{B}}\right) \text { \& South Africa }\left(\text { ZARUSD }^{\mathrm{B}}\right) \text {. }\end{array}$ & \multirow{2}{*}{ 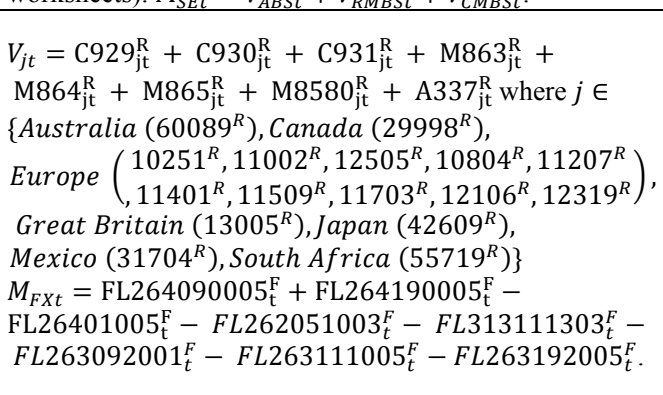 } \\
\hline & Covered Interest Spreads (CIS) & $\left(1+r_{t}^{*}\right)-\left(\frac{F_{t}}{S_{t}}\right)\left(1+r_{t}\right)$ & 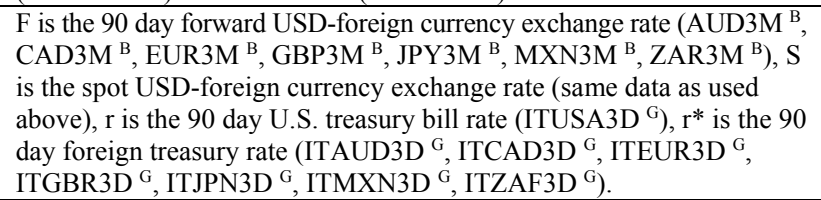 & \\
\hline
\end{tabular}

Note: We use superscripts to denote the source of our data as follows: ${ }^{\mathrm{B}}$ represents Bloomberg, ${ }^{\mathrm{D}}$ (Datastream), ${ }^{\mathrm{F}}$ (Financial Accounts for the U.S. Z1 report), ${ }^{\mathrm{G}}$ (Global

Financial Data), and ${ }^{\mathrm{H}}$ (Haver Analytics), ${ }^{\mathrm{R}}$ (FFIEC 009 Country Exposure Report). For weight data we scale as data as necessary to reconcile different reporting standards

(figures reported in thousands, millions, or billions). 
This construction recognizes the significant transformation in the financial system by including the growing breadth of the equity and the foreign exchange markets. However, we also recognize the importance of the real estate and securitization markets. The real estate market enables transactions in physical commercial and residential properties, where financial institutions act as various intermediaries. Stress in the real estate market may be observed through asset pricing pressures reflected by recent realized return on investment relative to alternative risk-free investments of like maturity. The securitization market facilitates transactions in securities backed by pools of transformed assets. We observe stress in the securitization market through asset pricing pressures of securitization assets-i.e., asset-backed securities (ABS), commercial mortgage-backed securities (CMBS), residential mortgage-backed securities (RMBS) - relative to risk-free investments of like maturity.

The FSI uses daily observable financial markets' data to capture continuity of stress in financial markets. The data is sourced from Bloomberg, Haver Analytics, Thomson Reuters' Datastream, Global Financial Data, Board of Governor's Financial Accounts for the US Z1 Report, Federal Financial Institutions Examination Council (FFIEC), and the Securities Industry and Financial Markets Association (SIFMA). Restricted by the historical depth of some data series, ${ }^{6}$ the development data set starts in the third quarter 1991. The variables for each of the six financial markets and their construction are outlined in Table 1.

\subsection{Variable Transformation and Aggregation}

Beyond the use of spreads as conceptually adequate variables for stress in individual markets, a further question is to the necessary transformation and aggregation of these variables to describe systemic conditions. To preserve the interpretation of indicators with distinct scales during aggregation, the cumulative density function (CDF) transformation is applied to each indicator $j$ following:

$$
C\left(x_{j t}\right)=100 * \frac{\operatorname{Rank}\left(x_{j t}\right)}{\text { number of observations }}
$$

This calculation can be completed using two potential partitions of the data: (1) the entire available time series (full information partition), or (2) all data up to each relevant time $t$ (cumulative partition). Under the assumption that the indicators of stress are stable over time, the full information approach provides a true comparison of stress across time by using all information to evaluate stress at each time $t$. With this approach, the past CDF series of each variable needs to be recalculated to incorporate the information from each additional observation. The corresponding reinterpretation of past observations makes this approach useful for historical analysis but somewhat less useful for forecasting (where we would prefer to easily partition in-sample and out-of-sample data). By contrast, the cumulative approach fixes stress at each time $t$, as it was perceived by market participants using the cumulative knowledge available to them at time $t$. As time goes on, the output from the cumulative approach becomes less volatile and converges towards the output of the full information approach, since the datasets they use become more similar.

\footnotetext{
6 The most severe constraint is Bloomberg's 10 year A Bank Bond Index $\left(\mathrm{C} 7010 \mathrm{Y}^{\mathrm{B}}\right)$ that is not available prior to 25
} September 1991. 
We compare the final FSI using both methods in Figure $2 .{ }^{7}$ Similar to the finding of [8], we find relatively little impact on the final stress index under the two transformation approaches. The remainder of this paper uses the full information approach to produce each value of the stress index.

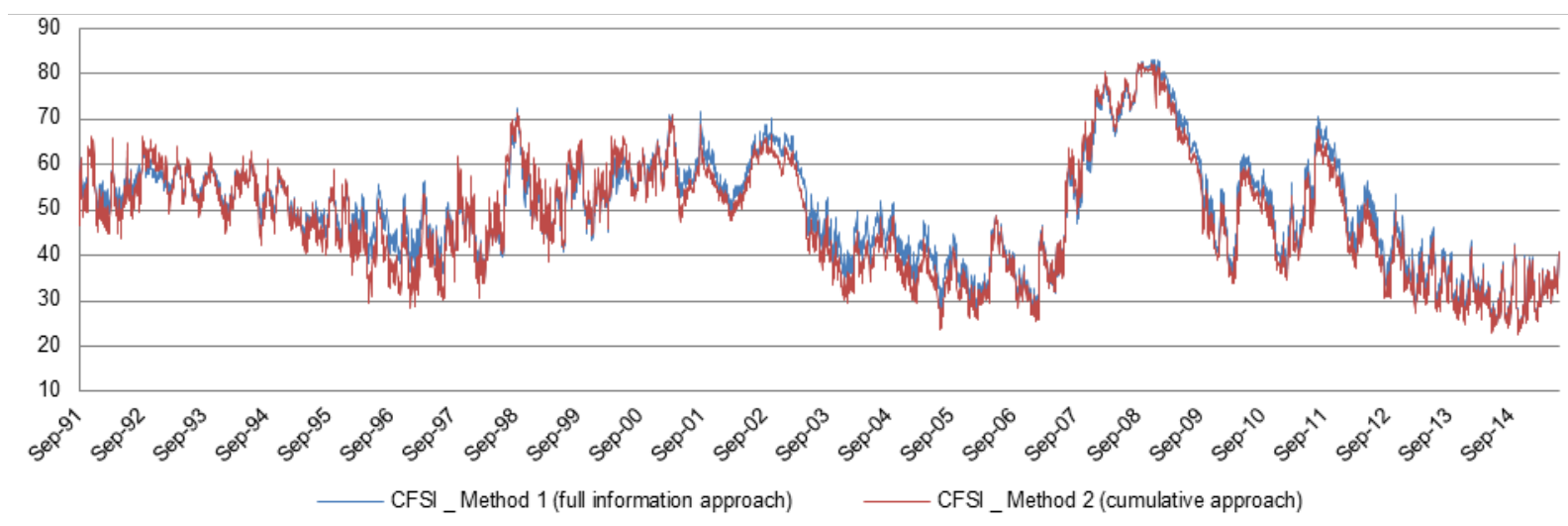

Figure 2. Comparison of CFSI using alternative approaches to CDF transformation.

The CDF transformation does distort the higher moments (for both approaches) in the process of fixing the mean and standard deviation of individual indicators. However, this does not remove the ability to interpret the output since the ordering of observations is preserved leading to an interpretation similar to percentiles. For instance, $C\left(x_{j t}\right)=90$ states that the observation $x_{j t}$ is greater than $90 \%$ of all observations; values close to 0 or 100 are produced when the indicator is lower or higher, respectively, than any other observation considered. For a collection of variables we invert the CDF following $C^{\prime}\left(x_{j t}\right)=1-C\left(x_{j t}\right)$ to preserve the intended interpretation that a higher CDF corresponds to higher stress. Indicators that are inverted are the equity crash indicators (where a lower value indicates a weakened demand or lower expected return from the instrument), and the treasury yield curve spread (since a flat or inverted yield curve has been connected to low growth prospects $[25,26]$ ). An alternative to the CDF method proposed by Bordo et al. [27] standardizes data by calculating the distance between each observation and the subperiod median divided by the standard deviation. We prefer the CDF standardization method which does not impose distributional assumptions on the data.

Leveraging multiple indicators to describe each market should increase the likelihood that market movement is attributable to a common factor, which can be interpreted as systemic financial stress. Since spreads in each market carry some amount of market-specific idiosyncratic noise, considering aggregate spreads across different markets is expected to reduce idiosyncratic noise. By definition, events due to systematic stress ought to affect spreads across multiple markets while we expect low correlation between the widening of spreads in separate markets if stress is non-systematic.

Several weighted aggregation methods are discussed in literature. ${ }^{8}$ Illing and Liu [28,29] test a number of alternative weighting schemes for a Canadian FSI and find that credit-weighted aggregation provides optimal identification of stress episodes for Canada. ${ }^{9}$ Oet et al. [10] conduct similar testing of

7 When applying the CDF transformation under cumulative approach we avoid heightened volatility for early observations by applying the full-information approach on the first $30 \%$ of our dataset as a training period.

8 Index construction in literature includes at least five aggregation methods: (1) equal weights, (2) equal variance weights, (3) credit weights, (4) principal component weights, and (5) portfolio weights (see [28-30]).

9 Illing and Liu [29] (p. 255) state that credit weights correspond to "the relative size of each market...as a share of total credit in the economy." 
various aggregation approaches for US data and construct a four-market Cleveland Financial Stress Index (four-market CFSI) using dynamic credit weights. Their method adjusts for the time-varying economic significance of the U.S. financial system markets.

$$
\begin{gathered}
w_{j t}=\frac{V_{j t}}{\sum_{j \in J_{i}} V_{j t}} \\
S_{E Q t}=\sum_{j \in J_{E Q}} w_{j t} S M C_{j t} \\
S_{S E t}=w_{R M B S t} R M B S_{t}+w_{C M B S t} C M B S_{t}+w_{A B S t} A B S_{t} \\
S_{R E t}=w_{R R E t} R R E_{t}+w_{C R E t} C R E_{t} \\
S_{F X t}=\sum_{j \in J_{F X}} w_{j t}\left(C C_{j t}+C I S_{j t}\right) / 2 \\
S_{C R t}=\left(C B S_{t}+C P T B S_{t}+L S_{t}+T Y C S_{t}\right) / 4 \\
S_{F D t}=\left(F B_{t}+B B S_{t}+I L S_{t}+I C O B_{t}\right) / 4 \\
w_{i t}=\frac{M_{i t}}{\sum_{i} M_{i t}} \\
C F S I_{t}=\sum_{i} w_{i t} S_{i t}
\end{gathered}
$$

Following the conceptual index design in Figure 1, we aggregate the financial system stress indicators in two steps. First, the stress indicators are gathered to create market-level stress indices for funding (FD), foreign exchange (FX), equity (EQ), credit (CR), real estate (RE), and securitization (SE) markets. Wherever the allocation of wealth $V_{j t}$ is known for indicators within a market, we use weights $w_{j t}$ for each indicator $j \in J_{i}$ in market $i \in\{E Q, S E, R E, F X\}$ following Equation (2). We use market capitalization data to aggregate stock market crash (SMC) indicators for ten sectors $J_{E Q}=$ $\{C O N S, C O N D, E N R S, F I N L, I N D U, H L T H, I N F T, M A T R, U T I L, T E L S\}$ used in the global industry classification standard (GICS) as equity market stress $S_{E Q}$ (see Equation (3)). SIFMA data on securities outstanding is used to prepare securitization market stress $S_{S E}$ in Equation (4) where $J_{S E}=$ $\{R M B S, C M B S, A B S\}$. Haver Analytics data on the investment in residential and commercial real estate is used to aggregate $J_{R E}=\{R R E, C R E\}$ into real estate stress $S_{R E}$ according to Equation (5). Cross-border claims from the FFIEC 009 report $^{10}$ are used to calculate foreign exchange stress $S_{F X}$ in Equation (6) across seven countries $J_{F X}=\{$ Australia,Canada, Europe,Great Britain,Japan, Mexico, South Africa $\}$ where equal weight is given to the indicators of currency crashes (CC) and covered interest spreads (CIS). If information on the allocation of wealth within a market is unavailable, we apply an equal weight to each indicator when calculating market stress. Specifically, we fix $w_{j t}=0.25$ to aggregate indicators into credit market stress $S_{C R}$ given by Equation (7) where $j \in J_{C R}=\{C B S, C P T B S, L S, T Y C S\}$. Similarly, we fix $w_{j t}=0.25$ to calculate funding market stress $S_{F D}$ according to Equation (8) where $j \in J_{F D}=\{F B, B B S, I L S, I C O B\}$. Finally, we aggregate the six market indices into a single index representing the financial system. Data on the allocation of wealth $\left(M_{i t}\right)$ among the six markets is collected from the Financial Accounts (Z1) report (for equity $M_{E Q}$, credit $M_{C R}$, funding $M_{F D}$, and foreign

10 The FFIEC 009 Country Exposure Report aggregate data is available at [31]. 
exchange $M_{F X}$ ), SIFMA (for securitization $M_{S E}$ ), and Haver Analytics (for real estate $M_{R E}$ ). We use $M_{i t}$ to construct dynamic credit weights $w_{i t}$ in Equation (9) where $i \in\{E Q, S E, R E, F X, C R, F D\}$. The weights $w_{i t}$ for each of the six markets (shown in Figure 3) aggregate market level stress $S_{i t}$ into financial system stress $\mathrm{CFSI}_{t}$ in Equation (10).

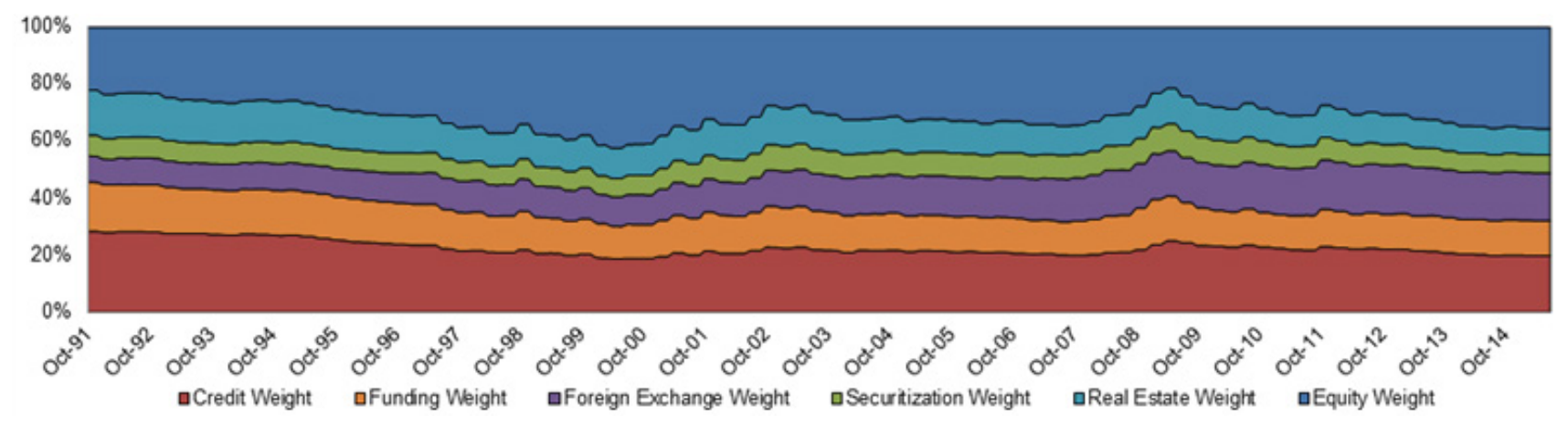

Figure 3. Credit weights used to calculate aggregate six-market CFSI.

\subsection{Evaluation}

Banking system crises are defined by [32-34] based upon the presence of deposit runs, introduction of deposit freezes or blanket guarantees, liquidity support, bank interventions. However, these definitions ignore market stresses that approach, but never meet crisis standards. Moreover, we are interested in crises that impact the entire financial system, not just the banking sector. Therefore, the reference benchmark for U.S. financial system combines multiple high-frequency volatility series (standardized using $z$-scores) following [21]. Stress is signaled when the value of a single volatility series is above a given threshold $\tau$ for two consecutive periods or when the values of two market indexes are above $\tau$ concurrently.

Moving beyond the intuitive appeal of a more detailed representation of the financial system, we initiate the evaluation of the six-market FSI, by testing whether the inclusion of the securitization and real estate markets improves the information quality of the stress measure. As shown in Table 2, the results support the inclusion of these additional markets based on improved information quality of the resulting stress measure. The noise to signal ratio (NTSR) is consistently below 0.3 and the information value $(I V)$ is between 0.3 and 0.6 . The thresholds for signaling stress can be chosen in two ways: maximizing the $I V$ metric or maximizing the relative usefulness $\left(U_{R}(\mu)\right)$ metric. Maximizing the $I V$ clearly improves relative usefulness $\left(U_{R}(\mu)\right)$ : as we expand the breadth of the index, $U_{R}(\mu)$ is moving closer to the best possible outcome of $U_{R}(\mu)=1$. Maximizing $U_{R}(\mu)$ preserves the trend of improvement through a steady increase in the $I V$ as additional markets are included. Moreover, the results show that the full six-market CFSI satisfies each of the three information quality criteria stipulated for a FSI $\left(N T S R<0.3,0.3<I V<0.6, U_{R}(\mu) \geq 0.3\right)$. 
Table 2. Estimating the value of information provided by variations of the FSI.

\begin{tabular}{|c|c|c|c|c|c|c|c|c|c|c|c|c|}
\hline & Name & $\tau_{F, i}^{l e v}$ & $\mathbf{T P}$ & FP & TN & $\mathbf{F N}$ & T1 & T2 & IV & NTSR & $\mu$ & $U_{R}(\mu)$ \\
\hline \multicolumn{13}{|c|}{ Panel 1: Comparison of value when maximizing $I V$} \\
\hline 1 & $\begin{array}{l}\text { Base four-market FSI and } \\
\text { real estate market }\end{array}$ & 1.13 & 651 & 92 & 4057 & 1034 & 0.61 & 0.02 & 0.5 & 0.06 & 0.7 & 0.36 \\
\hline 2 & Base four-market FSI & 1.46 & 439 & 82 & 4067 & 1246 & 0.74 & 0.02 & 0.5 & 0.08 & 0.7 & 0.24 \\
\hline 3 & $\begin{array}{c}\text { Base four-market FSI and } \\
\text { securitization market }\end{array}$ & 1.43 & 432 & 77 & 4072 & 1253 & 0.74 & 0.02 & 0.51 & 0.07 & 0.7 & 0.24 \\
\hline 4 & Full six-market FSI (CFSI) & 1.15 & 610 & 91 & 4058 & 1075 & 0.64 & 0.02 & 0.5 & 0.06 & 0.7 & 0.34 \\
\hline \multicolumn{13}{|c|}{ Panel 2: Comparison of value when maximizing $U_{R}(\mu)$} \\
\hline 1 & $\begin{array}{l}\text { Base four-market FSI and } \\
\text { real estate market }\end{array}$ & 0.68 & 992 & 346 & 3803 & 693 & 0.41 & 0.08 & 0.4 & 0.14 & 0.7 & 0.5 \\
\hline 2 & Full six-market FSI (CFSI) & 0.52 & 1083 & 696 & 3453 & 602 & 0.36 & 0.17 & 0.58 & 0.26 & 0.7 & 0.47 \\
\hline 3 & Base four-market FSI & 0.58 & 976 & 501 & 3648 & 709 & 0.42 & 0.12 & 0.33 & 0.21 & 0.7 & 0.45 \\
\hline 4 & $\begin{array}{c}\text { Base four-market FSI and } \\
\text { securitization market }\end{array}$ & 0.64 & 917 & 467 & 3682 & 768 & 0.46 & 0.11 & 0.39 & 0.21 & 0.7 & 0.43 \\
\hline
\end{tabular}

Note: $\tau_{B, D}^{l e v}=1$ and 4 bins were used for IV, the above results use daily CFSI and variations.

Table 3 (excerpt of Table 5 from Oet et al. [21]) provides the comparative results of testing information quality of alternative measures of financial stress. As shown, while most of the measures present beneficial noise to signal ratios, aggregate CFSI outperforms in terms of the relative usefulness. Descriptive statistics for the alternative stress measures are provided in Table 4.

Table 3. Comparison of information quality of alternative financial stress indices.

\begin{tabular}{lcccccccccccc}
\hline & Name & $\boldsymbol{\tau}_{\boldsymbol{F}, \boldsymbol{i}}^{\mathbf{l e v}}$ & $\mathbf{T P}$ & $\mathbf{F P}$ & $\mathbf{T N}$ & $\mathbf{F N}$ & $\mathbf{T 1}$ & $\mathbf{T 2}$ & $\mathbf{I V}$ & $\mathbf{N T S R}$ & $\boldsymbol{\mu}$ & $\boldsymbol{U}_{\boldsymbol{R}}(\boldsymbol{\mu})$ \\
\hline 1 & Full six-market FSI (CFSI) & 0.61 & 12 & 4 & 34 & 4 & 0.25 & 0.11 & 0.34 & 0.14 & 0.7 & 0.64 \\
2 & CFSI Securitization Market & 0.73 & 12 & 4 & 34 & 4 & 0.25 & 0.11 & 0.54 & 0.14 & 0.7 & 0.64 \\
3 & CFSI Real Estate Market & 0.94 & 9 & 2 & 36 & 7 & 0.44 & 0.05 & NA & 0.09 & 0.7 & 0.51 \\
4 & CFSI Equity Market & 0.65 & 11 & 7 & 31 & 5 & 0.31 & 0.18 & 0.46 & 0.27 & 0.7 & 0.50 \\
5 & CFNAI: Personal Consumption and Housing & 1.06 & 9 & 4 & 34 & 7 & 0.44 & 0.11 & 0.04 & 0.19 & 0.7 & 0.46 \\
6 & $\quad$ CFSI Credit Market & 1.05 & 7 & 3 & 35 & 9 & 0.56 & 0.08 & 0.18 & 0.18 & 0.7 & 0.36 \\
7 & CFNAI: Diffusion Index & 0.67 & 8 & 6 & 32 & 8 & 0.5 & 0.16 & 0.23 & 0.32 & 0.7 & 0.34 \\
8 & CFNAI: Three Month Moving Average & 0.85 & 6 & 3 & 35 & 10 & 0.63 & 0.08 & 0.38 & 0.21 & 0.7 & 0.29 \\
9 & CFNAI: Employment, Unemployment, and Hours & 0.89 & 6 & 3 & 35 & 10 & 0.63 & 0.08 & 0.38 & 0.21 & 0.7 & 0.29 \\
10 & Goldman Sachs Financial Conditions Index & 1.21 & 5 & 1 & 37 & 11 & 0.69 & 0.03 & 0.74 & 0.08 & 0.7 & 0.29 \\
11 & CFSI Funding Market & 1.23 & 5 & 1 & 37 & 11 & 0.69 & 0.03 & 0.13 & 0.08 & 0.7 & 0.29 \\
12 & St Louis Financial Stress Index & 0.64 & 6 & 3 & 35 & 10 & 0.63 & 0.08 & NA & 0.21 & 0.7 & 0.29 \\
13 & Bloomberg's Financial Conditions Index & 0.5 & 6 & 4 & 34 & 10 & 0.63 & 0.11 & NA & 0.28 & 0.7 & 0.27 \\
14 & National Financial Conditions Index (NFCI) & 0.86 & 5 & 2 & 36 & 11 & 0.69 & 0.05 & 0.77 & 0.17 & 0.7 & 0.26 \\
15 & CFNAI: Production and Income & 1.14 & 5 & 2 & 36 & 11 & 0.69 & 0.05 & 0.17 & 0.17 & 0.7 & 0.26 \\
16 & Kansas City Financial Stress Index & 0.61 & 5 & 3 & 35 & 11 & 0.69 & 0.08 & NA & 0.25 & 0.7 & 0.23 \\
17 & CFNAI: Sales, Orders, And Inventories & 1.48 & 4 & 1 & 37 & 12 & 0.75 & 0.03 & 0.03 & 0.11 & 0.7 & 0.22 \\
18 & NFCI: Nonfinancial Leverage Subindex & 0.8 & 5 & 4 & 34 & 11 & 0.69 & 0.11 & 0.04 & 0.34 & 0.7 & 0.21 \\
19 & CFSI Foreign Exchange Market & 0.55 & 6 & 10 & 28 & 10 & 0.63 & 0.26 & 0.32 & 0.7 & 0.7 & 0.11 \\
20 & NFCI: Leverage Subindex & 2 & 0 & 0 & 38 & 16 & 1 & 0 & 0.31 & NA & 0.1 & 0 \\
\hline
\end{tabular}


Table 4. Descriptive statistics for a collection of stress measures between 2002Q1 and 2013Q4.

\begin{tabular}{|c|c|c|c|c|c|c|c|}
\hline & Name & Maximum & Minimum & Mean & Std. Dev. & Skewness & Kurtosis \\
\hline 1 & Full six-market FSI (CFSI) & 81.70 & 31.39 & 50.28 & 13.39 & 0.69 & -0.40 \\
\hline 2 & CFSI Securitization Market & 10.25 & 1.68 & 4.76 & 2.29 & 1.00 & 0.20 \\
\hline 3 & CFSI Real Estate Market & 10.65 & 0.76 & 5.09 & 3.29 & 0.31 & -1.32 \\
\hline 4 & CFSI Equity Market & 27.88 & 6.92 & 15.57 & 6.11 & 0.44 & -0.97 \\
\hline 5 & CFNAI: Personal Consumption and Housing & -0.37 & 0.13 & -0.09 & 0.17 & -0.13 & -1.58 \\
\hline 6 & CFSI Credit Market & 18.09 & 5.38 & 10.29 & 2.97 & 0.49 & -0.03 \\
\hline 7 & CFNAI: Diffusion Index & -0.84 & 0.43 & -0.08 & 0.33 & -1.07 & 0.54 \\
\hline 8 & CFNAI: Three Month Moving Average & -3.73 & 0.55 & -0.31 & 0.85 & -2.61 & 7.23 \\
\hline 9 & CFNAI: Employment, Unemployment, and Hours & -1.55 & 0.27 & -0.14 & 0.36 & -2.14 & 5.24 \\
\hline 10 & Goldman Sachs Financial Conditions Index & 98.88 & 102.36 & 99.89 & 0.82 & 1.36 & 1.71 \\
\hline 11 & CFSI Funding Market & 14.49 & 3.68 & 6.71 & 2.59 & 1.62 & 2.38 \\
\hline 12 & St Louis Financial Stress Index & -1.26 & 5.24 & -0.06 & 1.23 & 2.45 & 7.64 \\
\hline 13 & Bloomberg's Financial Conditions Index & -8.63 & 1.09 & -0.62 & 1.72 & -2.65 & 9.61 \\
\hline 14 & National Financial Conditions Index (NFCI) & -0.90 & 2.70 & -0.31 & 0.70 & 2.58 & 7.75 \\
\hline 15 & CFNAI: Production and Income & -1.17 & 0.45 & -0.03 & 0.31 & -2.12 & 4.92 \\
\hline 16 & Kansas City Financial Stress Index & -0.91 & 5.33 & 0.18 & 1.24 & 2.62 & 7.82 \\
\hline 17 & CFNAI: Sales, Orders, And Inventories & -0.57 & 0.15 & -0.02 & 0.14 & -2.26 & 5.61 \\
\hline 18 & NFCI: Nonfinancial Leverage Subindex & -1.05 & 3.49 & 0.04 & 0.86 & 2.08 & 5.11 \\
\hline 19 & CFSI Foreign Exchange Market & 11.95 & 2.82 & 7.86 & 2.11 & -0.27 & -0.17 \\
\hline 20 & NFCI: Leverage Subindex & -1.36 & 2.70 & 0.27 & 1.37 & 0.54 & -1.09 \\
\hline
\end{tabular}

\section{Applications for Supervision}

\subsection{Monitoring Financial Stress}

Selecting the monitoring frequency for the CFSI to limit the impact of idiosyncratic events may further facilitate the analysis of systemic stress. Determining the extent of distress using high frequency data may result in a very volatile stress index with too many idiosyncratic stress episodes (market rumors, unsubstantiated fears, political events, etc.). Additionally, an optimal CFSI rating system may facilitate monitoring of systemic stress by guiding interpretation (see [27]). Therefore, we test a CFSI rating system that effectively demarcates the magnitude of stress combined with a monitoring frequency that filters out idiosyncratic episodes by comparing against the independent benchmark.

Bordo et al. [27] posit that a continuous index can be used for identification of distress severity independently of dating systemic conditions, using standardized distances from the median. They propose a five-state empirical decomposition of systemic conditions: severe distress $\left(Z_{t}>1.5\right)$, moderate distress $\left(1.5 \geq Z_{t}>0.75\right)$, normal $\left(0.75 \geq Z_{t}>-0.75\right)$, moderate expansion $(-0.75 \geq$ $\left.Z_{t}>-1.5\right)$, and euphoria with $\left(-1.5 \geq Z_{t}\right)$. We provide additional detail to this approach by testing alternative grade and threshold calibrations for a stress rating system. To construct this rating system, we divide the CFSI into grades (from three to five), determine how many observations fall into each grade, and compare those observations to the benchmark series. We calculate the receiver operating characteristic (ROC) curve metric and Somers' D to determine rating system's effectiveness. The area under the ROC curve is a measure of the differentiating power of the rating system. For a perfect rating 
system the ROC statistic measures one, while ROC for a rating system that is not better than random measures 0.5 . Somers' $D$ is a broad metric that shows the degree to which a low rating within the system contains excess stress events. ${ }^{11}$

$$
\text { Somers }^{\prime} \mathrm{D}=2 * P\left(\text { Rating Grade }_{\text {stress }}>\text { Rating Grade }_{\text {no stress }}\right)+P\left(\text { Rating Grade }_{\text {stress }}=\text { Rating Grade }_{\text {no stress }}\right)-1
$$

Considering the results in Table 5, it is interesting to note that for low thresholds (from 0.5 to 1.1) there is relative parity between weekly and biweekly monitoring. As the threshold used to denote a crisis is increased (between 1.4 and 1.7) a modest but persistent advantage is observable with the weekly frequency using three grades. However, we achieve a maximum ROC score of 0.90 and a Somers' D of 0.80 which support a biweekly five-grade rating system. Figure 4 shows the resulting implementation of the biweekly five-grade CFSI against the binary benchmarked episodes of stress. This approach contributes to current literature on monitoring applications of continuous index measures, which generally report the indexes in standardized form without providing explicit thresholds to guide the interpretation of distress severity.

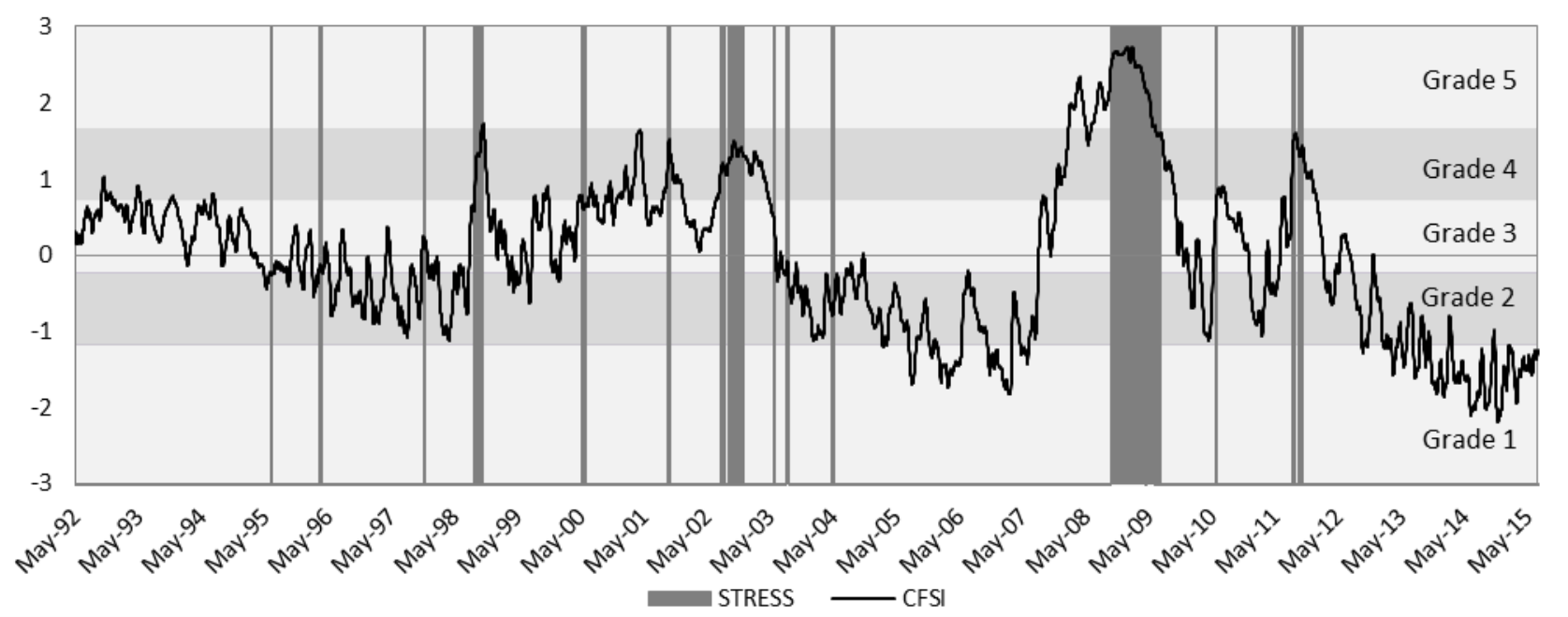

Figure 4. CFSI, grades, and benchmark index of systemic stress episodes.

11 Technically, it is a measure of association describing the difference of the conditional probabilities (see [35]). We find that in all cases the ROC and Somers' D agree on which settings produce the optimal measure. 
Table 5. Systemic stress episodes and non-parametric testing of rating system.

\begin{tabular}{|c|c|c|c|c|c|c|c|c|c|c|c|}
\hline Frequency & Threshold & $\begin{array}{c}\text { Stress } \\
\text { Observations }\end{array}$ & $\begin{array}{c}\text { Non-Stress } \\
\text { Observations }\end{array}$ & $\begin{array}{c}\text { Percent } \\
\text { Stress } \\
\text { Observations } \\
\end{array}$ & $\begin{array}{l}\text { Periods } \\
\text { of Stress }\end{array}$ & $\begin{array}{l}\text { ROC } 3 \\
\text { Grades }\end{array}$ & $\begin{array}{l}\text { ROC } 4 \\
\text { Grades }\end{array}$ & $\begin{array}{l}\text { ROC } 5 \\
\text { Grades }\end{array}$ & $\begin{array}{c}\text { Somers' D } \\
3 \text { Grades }\end{array}$ & $\begin{array}{c}\text { Somers' D } \\
4 \text { Grades }\end{array}$ & $\begin{array}{c}\text { Somers' D } \\
5 \text { Grades }\end{array}$ \\
\hline Weekly & 0.5 & 2757 & 5728 & 0.325 & 102 & 0.771 & 0.767 & 0.808 & 0.542 & 0.533 & 0.617 \\
\hline Biweekly & 0.5 & 2757 & 5728 & 0.325 & 102 & 0.771 & 0.758 & 0.807 & 0.542 & 0.516 & 0.615 \\
\hline Monthly & 0.5 & 2757 & 5728 & 0.325 & 102 & 0.770 & 0.748 & 0.801 & 0.539 & 0.497 & 0.601 \\
\hline Quarterly & 0.5 & 2757 & 5728 & 0.325 & 102 & 0.734 & 0.730 & 0.793 & 0.468 & 0.460 & 0.586 \\
\hline Weekly & 0.8 & 1915 & 6570 & 0.226 & 88 & 0.787 & 0.774 & 0.816 & 0.574 & 0.548 & 0.632 \\
\hline Biweekly & 0.8 & 1915 & 6570 & 0.226 & 88 & 0.784 & 0.767 & 0.816 & 0.567 & 0.534 & 0.631 \\
\hline Monthly & 0.8 & 1915 & 6570 & 0.226 & 88 & 0.782 & 0.757 & 0.809 & 0.564 & 0.514 & 0.618 \\
\hline Quarterly & 0.8 & 1915 & 6570 & 0.226 & 88 & 0.741 & 0.736 & 0.796 & 0.482 & 0.472 & 0.592 \\
\hline Weekly & 1.1 & 1272 & 7213 & 0.150 & 61 & 0.818 & 0.790 & 0.828 & 0.636 & 0.579 & 0.655 \\
\hline Biweekly & 1.1 & 1272 & 7213 & 0.150 & 61 & 0.811 & 0.786 & 0.830 & 0.623 & 0.572 & 0.659 \\
\hline Monthly & 1.1 & 1272 & 7213 & 0.150 & 61 & 0.805 & 0.779 & 0.820 & 0.609 & 0.557 & 0.640 \\
\hline Quarterly & 1.1 & 1272 & 7213 & 0.150 & 61 & 0.752 & 0.750 & 0.803 & 0.503 & 0.500 & 0.607 \\
\hline Weekly & 1.4 & 948 & 7537 & 0.112 & 44 & 0.843 & 0.806 & 0.839 & 0.686 & 0.612 & 0.679 \\
\hline Biweekly & 1.4 & 948 & 7537 & 0.112 & 44 & 0.832 & 0.805 & 0.841 & 0.664 & 0.609 & 0.682 \\
\hline Monthly & 1.4 & 948 & 7537 & 0.112 & 44 & 0.816 & 0.798 & 0.834 & 0.632 & 0.597 & 0.669 \\
\hline Quarterly & 1.4 & 948 & 7537 & 0.112 & 44 & 0.757 & 0.768 & 0.814 & 0.514 & 0.537 & 0.628 \\
\hline Weekly & 1.7 & 680 & 7805 & 0.080 & 39 & 0.859 & 0.823 & 0.850 & 0.719 & 0.647 & 0.701 \\
\hline Biweekly & 1.7 & 680 & 7805 & 0.080 & 39 & 0.846 & 0.819 & 0.852 & 0.691 & 0.638 & 0.705 \\
\hline Monthly & 1.7 & 680 & 7805 & 0.080 & 39 & 0.829 & 0.812 & 0.846 & 0.658 & 0.624 & 0.693 \\
\hline Quarterly & 1.7 & 680 & 7805 & 0.080 & 39 & 0.769 & 0.796 & 0.826 & 0.537 & 0.592 & 0.651 \\
\hline Weekly & 2 & 482 & 8003 & 0.057 & 30 & 0.898 & 0.867 & 0.897 & 0.796 & 0.733 & 0.793 \\
\hline Biweekly & 2 & 482 & 8003 & 0.057 & 30 & 0.888 & 0.861 & 0.900 & 0.775 & 0.722 & 0.800 \\
\hline Monthly & 2 & 482 & 8003 & 0.057 & 30 & 0.870 & 0.856 & 0.897 & 0.741 & 0.712 & 0.795 \\
\hline Quarterly & 2 & 482 & 8003 & 0.057 & 30 & 0.824 & 0.841 & 0.875 & 0.648 & 0.682 & 0.750 \\
\hline
\end{tabular}




\subsection{Analyzing Financial Stress}

\subsubsection{Decomposition of Financial Stress}

In the presence of elevated or rising aggregate stress it may also be helpful to decompose stress and isolate the primary factors responsible. As shown in Figure 3, the weights of CFSI's six market components and their relative importance fluctuate over time. For example, the weight for the funding market increased from 0.12 to 0.15 from 2008 to 2009 . Conversely, the weight for the equity markets decreased from nearly 0.43 in early 2000 to roughly 0.21 in 2009.

Figure 5 shows the movements of specific markets within the biweekly CFSI, providing insight into the amount of stress that the six distinct markets contributed to the overall stress series. Measures from all markets tend to contribute significantly to overall financial stress. Their contributions in periods of financial stress tend to rise and fall together, collectively moving aggregate financial stress. This correlated behavior of stress components does have some exceptions. Consider, for example, the evolution of the subprime crisis of 2007-2010. There was an observed initial stress increase in all six markets composing the CFSI at differing times. As the crisis progressed and the Federal Reserve took extraordinary steps to mitigate this stress, CFSI shows a decrease in overall stress starting in early 2009. The most marked drop-offs in stress were first apparent in the CFSI's securitization market component, followed by stress declines in others such as equity and funding markets. A similar, but less dramatic pattern can be observed in the latent phase of the Long-Term Capital Management (LTCM) crisis of 1998. Federal Reserve stabilizing measures lowered stress in the equity markets first, followed by lower stress in the credit market.

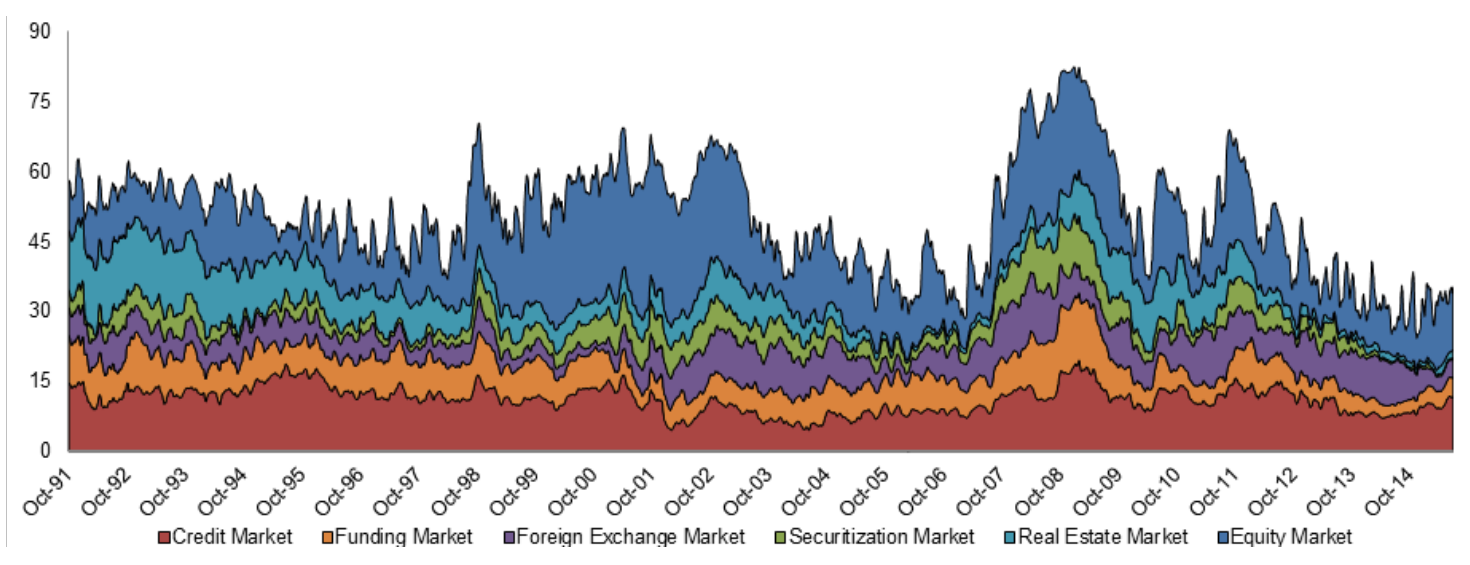

Figure 5. CFSI decomposed into market stress.

Observations from individual markets of the financial stress index offer substantial information about components of stress in each market. Each panel of Figure 6 decomposes stress in a different market. The first two panels display the components of the funding and credit markets. The funding market contributed the most to overall financial stress during the recent financial crisis. In the initial phase of the subprime crisis, from March to July 2007, funding market stress was primarily driven by growing interbank liquidity spread and bank bond spread. The financial beta accentuated stress only after December 2007. Interbank cost of borrowing became a factor at the height of the crisis, from March 2008 to May 2009. Beginning in May 2009, interbank costs decreased as the Federal Reserve began decreasing the federal funds rate among other less conventional tools. The contributions of the credit 
market to CFSI remain relatively constant with time. At the onset of the subprime crisis, credit markets' change in stress was mainly driven by increases in the commercial paper-T-bill spread, with other spreads remaining relatively steady. At the height of the crisis, from March 2008 to October 2009, increases in the corporate bond spread and the commercial paper-T-bill spread were the most significant, accentuated by the liquidity spread.

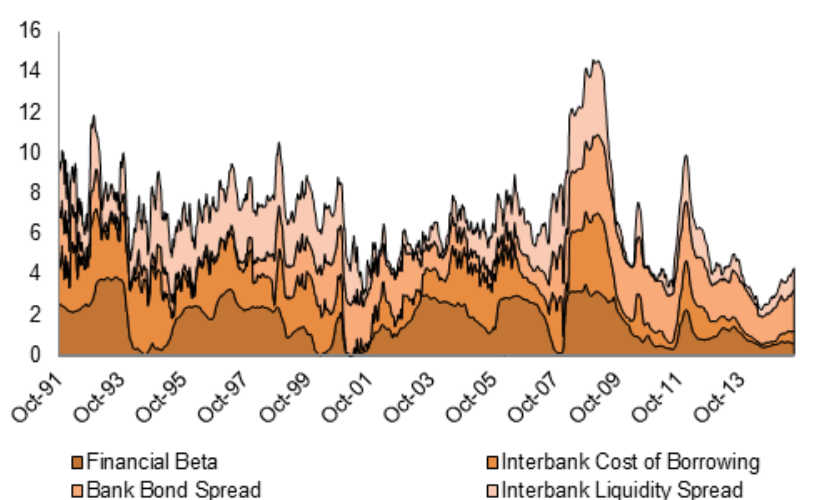

(a) Funding market

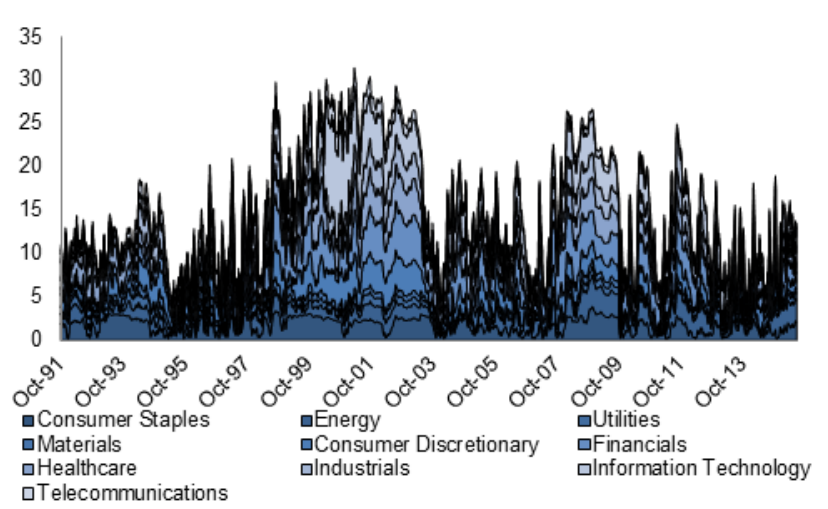

(c) Equity market

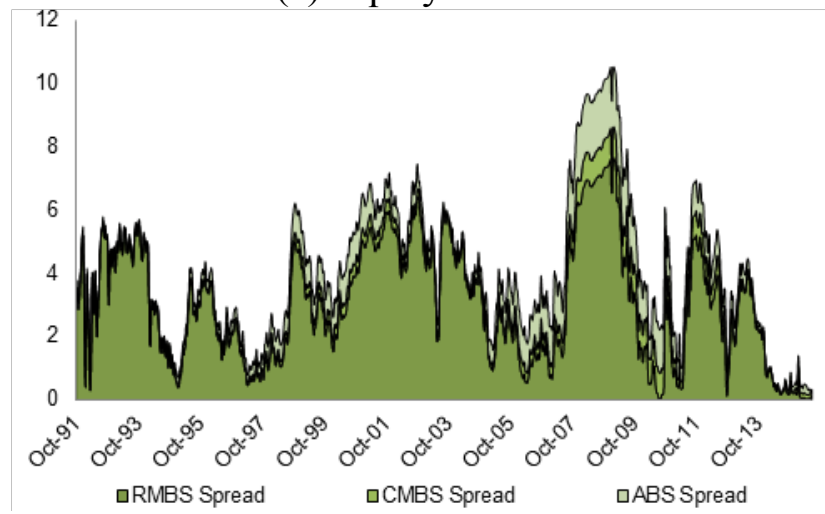

(e) Securitization market

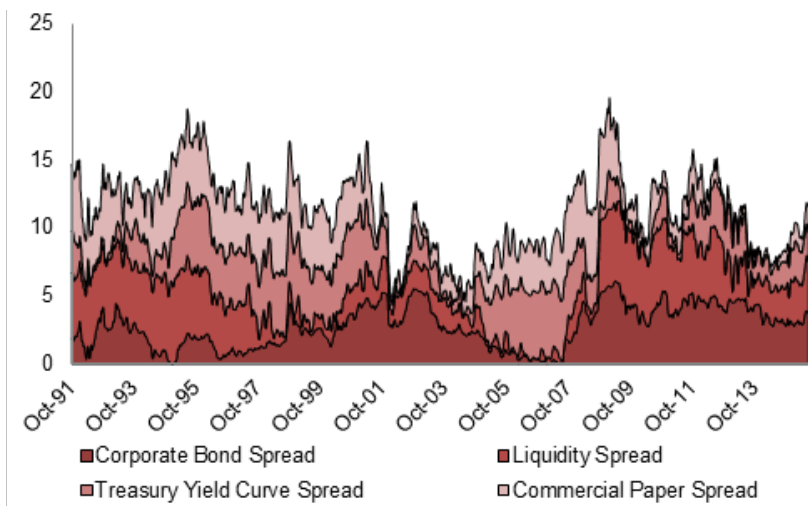

(b) Credit market

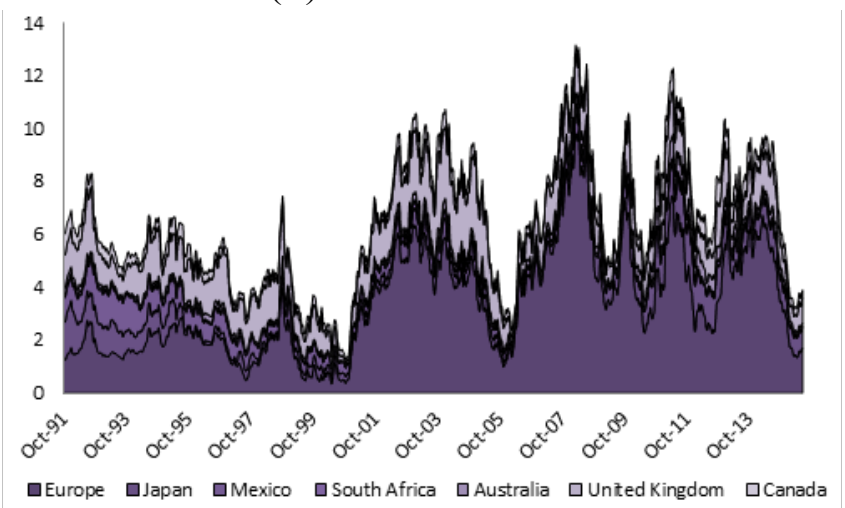

(d) Foreign exhange market

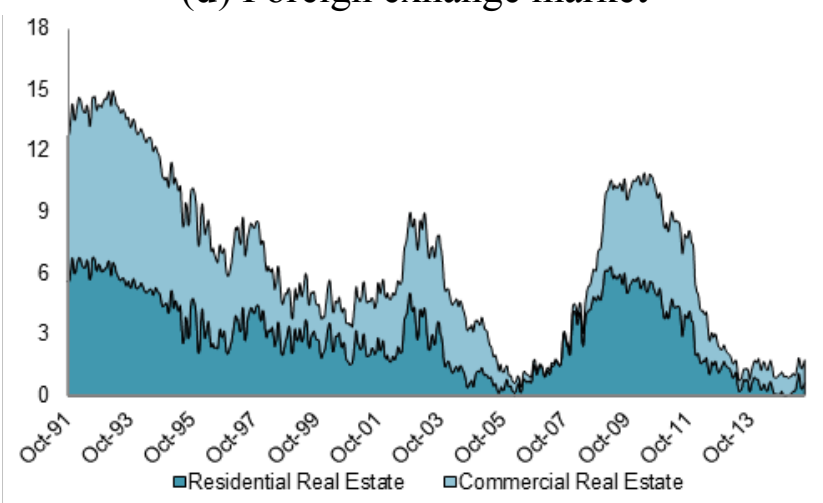

(f) Real estate market

Figure 6. Decomposition of stress: Components of the funding (a), credit (b), equity (c), foreign exchange (d), securitization (e), and real estate (f) markets.

Panels (c) and (d) of Figure 6 decompose overall financial stress in the equity and foreign exchange markets. The equity market contributed most significantly to stress during the Dot-Com Bubble. At this time, the contributions of the information technology component of the market significantly surpass the contributions of the other components of the equity market. During the most recent financial crisis, both 
the information technology and financial components of the equity market contributed significantly to stress. Contributions from the foreign exchange market were largest more recently in conjunction with the recent subprime crisis and European debt crisis.

The final two panels of Figure 6 decompose stress in the securitization and real estate markets. Securitization markets contributed to stress most significantly during the financial crisis with the large majority of stress stemming from the RMBS indicator due to the relative size of RMBS activity. Real estate indicators contributed most significantly to overall financial stress in the early 1990s, early 2000s, and again during the recent financial crisis. Perceived stress in the real estate market during the recent financial crisis was manifest between early 2008 and late 2011, beginning somewhat later than stress in the other indicators but persisting much longer period.

\subsubsection{Retrospective and Prospective Analysis}

The link between regulation and systemic crises has been widely studied in literature. Miron [36] finds evidence of seasonal banking panics prior to the creation of the Federal Reserve. Freixas and Rochet [37] connect financial deregulation to financial crises through several empirical studies. Kaminsky and Reinhart [38] (p. 480) suggest that "crises may have common origins in the deregulation of the financial system and the boom-bust cycles and asset bubbles that, all too often, accompany financial liberalization." Caprio and Klingebiel [39] provide cross-country evidence of a natural lag between financial liberalization and adjustment of regulatory structure and supervisory practices, which may partially explain the link between deregulation and banking crises. ${ }^{12}$

Therefore, considering financial stress retrospectively, we expect to find multiple structural breaks in the average level of financial stress. We use Bai-Perron's test for multiple structural breaks to search for breaks at dates within the 15\% trimmed biweekly series [40]. As Table 6 and Figure 7 show, five statistically significant breaks are found in the aggregate CFSI in April 1995, January 2000, August 2003, November 2007, and December 2011.

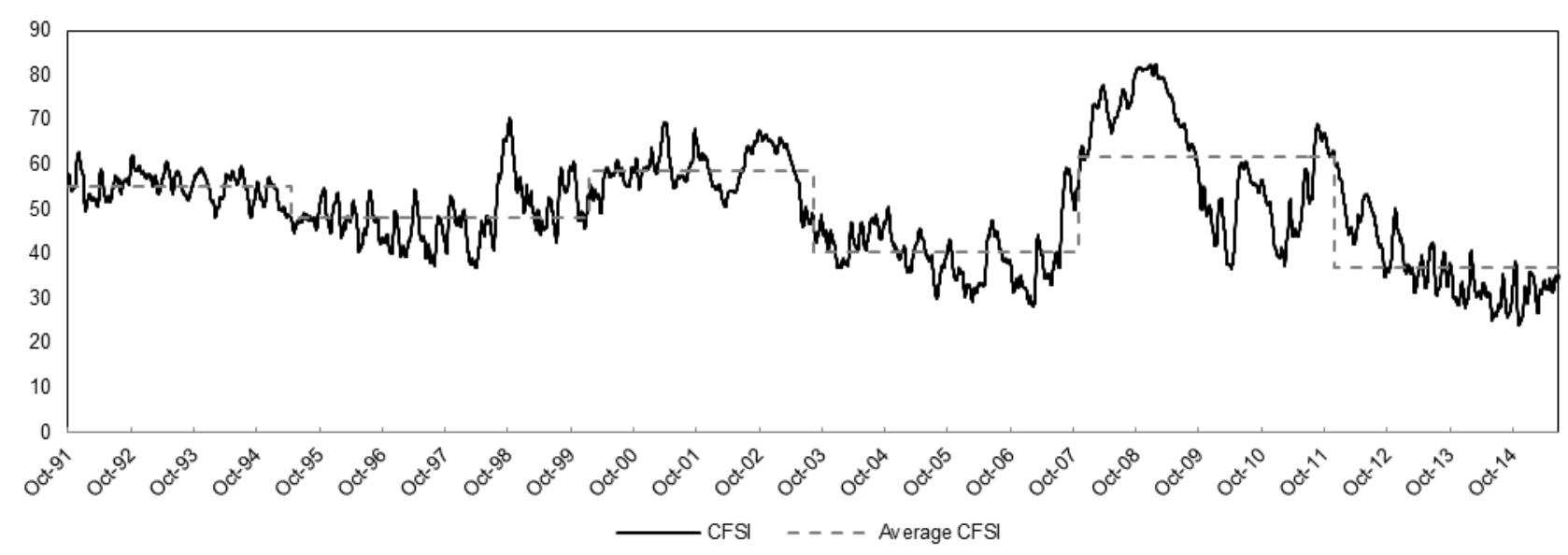

Figure 7. Structural breaks in the CFSI.

12 See [41-44] for studies of deregulation and banking instability. 
Table 6. Bai-Perron testing for structural breaks in CFSI and its markets.

\begin{tabular}{|c|c|c|c|}
\hline Break Test & F-statistic & Number of Breaks & Break Dates \\
\hline \multicolumn{4}{|c|}{ Panel A: Breaks in CFSI } \\
\hline 0 vs. $1 * * *$ & 2367.45 & 1 & $12 / 07 / 2011$ \\
\hline 1 vs. $2 * * *$ & 733.63 & 2 & $11 / 08 / 2007$ \\
\hline 2 vs. $3 * * *$ & 3189.95 & 3 & $08 / 20 / 2003$ \\
\hline $3 v s .4 * * *$ & 1127.83 & 4 & $01 / 20 / 2000$ \\
\hline 4 vs. $5 * * *$ & 1001.81 & 5 & $4 / 27 / 1995$ \\
\hline \multicolumn{4}{|c|}{ Panel B: Breaks in funding CFSI subcomponent } \\
\hline 0 vs. $1 * * *$ & 2575.82 & 1 & $12 / 04 / 2009$ \\
\hline 1 vs. $2 * * *$ & 473.59 & 2 & $05 / 24 / 2006$ \\
\hline $2 v s .3 * * *$ & 2212.52 & 3 & $12 / 20 / 2000$ \\
\hline 3 vs. $4 * * *$ & 65.02 & 4 & $04 / 27 / 1995$ \\
\hline 4 vs. 5 & 0.00 & - & - \\
\hline \multicolumn{4}{|c|}{ Panel C: Breaks in credit CFSI subcomponent } \\
\hline 0 vs. $1 * * *$ & 1835.38 & 1 & $06 / 20 / 2001$ \\
\hline $1 v s .2 * * *$ & 2288.24 & 2 & $08 / 14 / 2007$ \\
\hline 2 vs. $3 * * *$ & 608.36 & 3 & $12 / 07 / 2011$ \\
\hline $3 v s .4 * * *$ & 282.20 & 4 & 05/20/1996 \\
\hline 4 vs. $5 *$ & 0.00 & - & - \\
\hline \multicolumn{4}{|c|}{ Panel D: Breaks in equity CFSI subcomponent } \\
\hline $0 v s .1 * * *$ & 1664.50 & 1 & $05 / 05 / 1998$ \\
\hline 1 vs. $2 * * *$ & 3961.59 & 2 & $06 / 05 / 2003$ \\
\hline 2 vs. $3 * * *$ & 537.28 & 3 & $12 / 07 / 2011$ \\
\hline $3 v s .4 * * *$ & 557.72 & 4 & $07 / 31 / 2007$ \\
\hline 4 vs. 5 & 0.00 & - & - \\
\hline \multicolumn{4}{|c|}{ Panel E: Breaks in foreign exchange CFSI subcomponent } \\
\hline 0 vs. $1 * * *$ & 3563.92 & 1 & $08 / 23 / 2001$ \\
\hline $1 v s .2 * * *$ & 2335.17 & 2 & $01 / 27 / 1997$ \\
\hline $2 v s .3 * * *$ & 280.28 & 3 & $03 / 23 / 2005$ \\
\hline $3 v s .4 * * *$ & 77.66 & 4 & $10 / 04 / 2010$ \\
\hline 4 vs. 5 & 0.00 & - & - \\
\hline \multicolumn{4}{|c|}{ Panel F: Breaks in real estate CFSI subcomponent } \\
\hline 0 vs. $1 * * *$ & 11335.27 & 1 & $12 / 04 / 1995$ \\
\hline $1 v s .2 * * *$ & 4001.06 & 2 & $12 / 07 / 2011$ \\
\hline $2 v s .3 * * *$ & 3241.51 & 3 & $05 / 20 / 2008$ \\
\hline $3 v s .4 * * *$ & 5885.21 & 4 & $07 / 13 / 2004$ \\
\hline 4 vs. $5 * * *$ & 389.05 & 5 & $06 / 30 / 1999$ \\
\hline \multicolumn{4}{|c|}{ Panel G: Breaks in securitization CFSI subcomponent } \\
\hline 0 vs. $1 * * *$ & 822.20 & 1 & $12 / 07 / 2011$ \\
\hline $1 v s .2 * * *$ & 646.98 & 2 & $07 / 30 / 2007$ \\
\hline $2 v s .3 * * *$ & 968.38 & 3 & $08 / 27 / 1998$ \\
\hline $3 v s .4 * * *$ & 2043.40 & 4 & $01 / 26 / 2004$ \\
\hline 4 vs. 5 & 0.00 & - & - \\
\hline
\end{tabular}


The first break in August of 1995 may be due to a shift between the end in a series of protracted stress episodes of the early 1990s (US savings and loan crisis, bond market crisis, and Mexican crisis) and relative stability in later 1990s. The environment of temperate stress in the second regime was briefly broken in 1998 by the interconnected global wave of crises from the Asian and Russian crises to the LTCM crisis. The second break, in January 2000, coincides roughly with the dot-com bubble and a period of persistent heightened stress. The third structural break, in August 2003, coincides closely with the global equities rebound. The fourth and fifth structural breaks, in November of 2007 and December of 2011 respectively, correspond to the beginning and end of the financial crisis (Table 6, Panel A).

Interestingly, multiple structural break tests performed on the markets of CFSI (Table 6, Panel B-G) indicate that the markets may exhibit some temporal independence from the CFSI due to the lack of shared break dates. Many of the market-specific breaks occur close to one another and could indicate inter-market contagion effects. For example, the November 2007 structural break in the overall CFSI was preceded by the May 2006 break in the funding market. This was followed by the July and August 2007 sequential breaks in the securitization, equity, and credit markets, and succeeded by the May 2008 break in the real estate market. While analysis of these structural breaks may provide ex-post understanding of inter-market stress, it offers no real time benefit due to the inherent nature of structural break tests. Using trimmed data in the break test can only detect recent breaks with a significant lag. Thus, other alerting mechanisms are needed to apply CFSI for prospective insights into emergent stress.

Table 7. Granger causality testing

\begin{tabular}{|c|c|c|}
\hline Hypothesis & F-Statistic & Probability \\
\hline \multicolumn{3}{|c|}{ Panel A: CFSI, bank failures, and economic growth } \\
\hline$C F S I_{M}$ does not Granger cause number of defaults & $2.781 \dagger \dagger$ & 0.032 \\
\hline Number of defaults does not Granger cause $C F S I_{M}$ & $0.758^{(\mathrm{ns})}$ & 0.555 \\
\hline$C F S I_{M}$ does not Granger cause estimated loss & $3.490 \dagger$ & 0.011 \\
\hline Estimated loss does not Granger cause $C F S I_{M}$ & $0.343^{\text {(ns) }}$ & 0.849 \\
\hline$C F S I_{t}$ does not Granger cause GNP growth & $1.801^{\dagger}$ & 0.137 \\
\hline GNP growth does not Granger cause $C F S I_{t}$ & $0.740^{(\mathrm{ns})}$ & 0.567 \\
\hline Estimated loss does not Granger cause the number of defaults & $14.604^{\dagger \dagger}$ & 0.000 \\
\hline Number of defaults does not Granger cause the estimated loss & $2.927^{\dagger \dagger \dagger}$ & 0.026 \\
\hline Estimated loss does not Granger cause the GNP growth & $4.986^{\dagger \dagger \dagger}$ & 0.001 \\
\hline GNP growth does not Granger cause the estimated loss & $6.004^{\dagger \dagger \dagger}$ & 0.000 \\
\hline Number of defaults does not Granger cause the GNP growth & $0.033^{(\mathrm{ns})}$ & 0.998 \\
\hline GNP growth does not Granger cause the number of defaults & $6.000^{\dagger \dagger \dagger}$ & 0.000 \\
\hline \multicolumn{3}{|c|}{ Panel B: CFSI and effective federal funds rate } \\
\hline$C F S I_{t}$ does not Granger cause the effective federal funds rate & $1.937^{\dagger \dagger}$ & 0.031 \\
\hline The effective federal funds rate does not Granger cause $C F S I_{t}$ & $2.200+\dagger$ & 0.012 \\
\hline
\end{tabular}
Notes: $\uparrow$-indicates Granger causality at $85 \%$; $\uparrow \dagger$-indicates Granger causality at $90 \%$; $\uparrow \uparrow \uparrow$-indicates Granger causality at 95\%; (ns) — indicates no significance at 15\%. Panels A uses quarterly data between Q4 1991 and Q2 2015 with 4 quarters lagged. Panel B uses monthly data between October 1991 and June 2015 with 12 months lagged.

To this end, we consider whether CFSI as a measure of coincident financial stress provides prospective insights on the future state of realized distress in the financial system, growth in economic activity, or monetary policy. Our data sample from December 1991 to June 2015 contains at least two 
full business cycles according to the National Bureau of Economic Research and can be considered adequate for this analysis. We first test for Granger causality between CFSI, Federal Deposit Insurance Corporation (FDIC) quarterly bank defaults and aggregate loss data, and gross national product (GNP) growth. ${ }^{13}$ The analysis suggests an interesting story about the direction of Granger causality among these variables. Following the results presented in Panel A of Table 7, there is evidence that CFSI Granger causes the number of defaults and aggregate loss. Moreover, we find evidence that the state of financial system stress weakly Granger causes growth in economic activity. This impact of financial system stress on economic growth may be explained by a causal chain through aggregate loss. In Panel B we find evidence of significant bidirectional Granger causality between financial stress and monetary policy supporting the existence of the interdependent feedback between monetary policy and financial stability.

\subsection{Alerting Financial Stress}

As an additional perspective for interpreting stress, we estimate the probability that there is currently a systemic crisis given the level of stress following the logit model in Equation (12). The implied probability of a crisis event according to Equation (12) is shown in Figure 8. Visually, the probability of a concurrent systemic crisis predicted through the estimated logistic regression model is somewhat less noisy.

$$
\log \left(\frac{\pi t 1}{\pi_{t 0}}\right)=\alpha+\beta Z\left(C F S I_{t}\right)=-4.77+2.26 * Z\left(C F S I_{t}\right)
$$

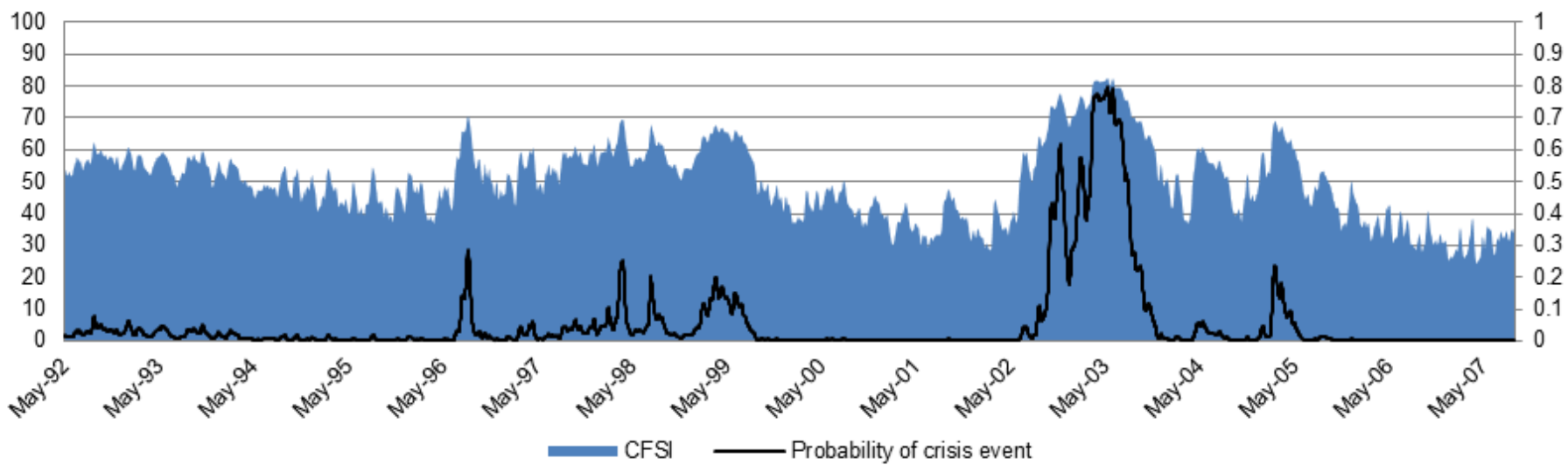

Figure 8. Implied probability of system stress episode (right axis) given the level of CFSI (left axis).

Patterns in the volatility of asset returns change over time and across markets (see [45-47]). The supervisor is particularly interested in the relationship of stress within a particular market to financial system stress, how it may change over time, and what aspects of the changing pattern the supervisor should watch out for.

Here, the operational logic of CFSI's systemic stress identification provides a valuable roadmap — systemic stress is two consecutive periods of distress (increase in stress above a threshold $\tau$ ),

13 FDIC data on bank failures can be found at [48]. We omit all defaults supervised by the Resolution Trust Corporation (RTC) due to suspected discrepancies in the reporting methodology of estimated loss. We use the Datastream series USGNP... $\mathrm{D}^{\mathrm{D}}$ and FRFEDFD ${ }^{\mathrm{D}}$ for GNP and effective federal funds rate respectively. We use the difference in the logarithm of reported GNP as GNP growth. 
or concurrent distress in at least two distinct markets. This approach enables the supervisor to observe significant stress alerts both within a particular market and in the system. Figure 9 graphs the alerts decomposed by market against stress.

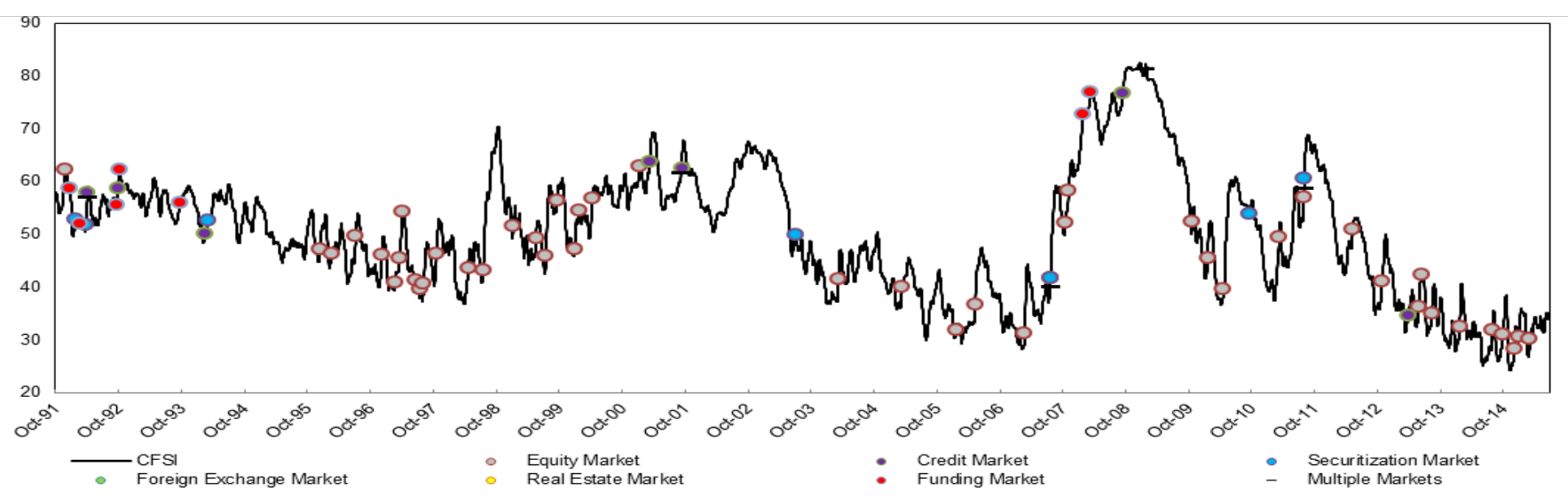

Figure 9. CFSI with alerts by market.

Observing signals of stress in individual markets filtered through the monitoring threshold $\tau$ (Figure 9), the supervisor perceives systemic stress alarms in the securitization market in July 2007. This alert is followed by alerts in the equity market (in October and November 2007), funding markets in (January and March 2008), and credit markets (September 2008). These alerts accurately highlight the markets driving the development of systemic stress at the very onset of the crisis. Therefore, observant supervisors would recognize a systemic stress episode sometime between July and November 2007.

\section{Conclusions}

We develop an extended financial stress measure, the six-market CFSI, which considers the supervisory objective of identifying risks to the stability of the financial system through its multiple core markets. We demonstrate that CFSI improves the information quality of financial system stress measurement through an expanded set of indicators and markets. Both the information quality of CFSI and the effectiveness of CFSI rating system are tested against an independent benchmark of financial system disturbances combining multiple volatility series for the financial system. CFSI's construction, evaluation, and calibration methodology addresses the appropriateness of changing financial system composition and selects the optimal monitoring frequency.

We apply CFSI for the distinct supervisory applications of monitoring, analyzing, and alerting. We consider quantitatively whether a modestly lower frequency, in conjunction with a straightforward grading system may filter out idiosyncratic noise and facilitate interpretation for monitoring. Analytical applications of CFSI leverage the transparency of its hierarchical decomposition and allow supervisors to observe the disparate dynamics of multiple markets. The alerting applications of CFSI are directed to allow supervisors to perceive the onset of a crisis. These applications include probabilistic assessment that a systemic crisis is occurring and signaling heuristics for an emergent materially persistent stress within a single market and across multiple markets.

A potential historical extension of this stress measure appears promising not only for dating, comparing, and analyzing systemic episodes, but as a richer source of information relevant for an 
improved evaluation of current conditions. Another interesting research direction may seek to leverage the multiple-market stress construction to measuring stress in the financial systems of multiple countries.

The evaluation criteria for financial stress provide an additional course for future work. For example, it would be relevant to address whether additional financial agent and instrument detail improves the information quality of stress measurement. Further research can examine whether multilevel effects are present in aggregation of stress from the levels of financial instruments and financial agents to the level of financial system stress. As additional market detail is provided, it is appropriate to examine whether there are potential information quality trade-offs between the more detailed and more parsimonious measurements.

\section{Acknowledgments}

This paper represents the views of the individual authors and is not to be considered as the views of the Federal Reserve Bank of Cleveland or the Federal Reserve System. The authors are grateful to Joseph Haubrich, Ben Craig, Edward S. Knotek II, Manfred Kremer, Marco Lo Duca, Tuomas Peltonen, Viral Acharya, and Mark Flood for constructive feedback, and to Tim Bianco for critiques and research assistance. The authors are grateful to two anonymous reviewers for insightful and critical comments on an earlier version of the paper. The authors also thank the participants of the International work-conference on Time Series (Granada, 25-27 June 2014), the IRMC conference on "The Safety of the Financial System -From Idiosyncratic to Systemic Risk" (Warsaw, 23-24 June 2014), the $6^{\text {th }}$ International IFABS Conference on “Alternative Futures for Global Banking: Competition, Regulation and Reform” (Lisbon, 18-20 June 2014), and the $12^{\text {th }}$ INFINITI conference on international finance (Prato, 9-10 June 2014) for helpful comments and suggestions.

\section{Author Contributions}

All authors contributed materially to conceptual development of the paper and writing.

\section{Conflicts of Interest}

The authors declare no conflict of interest.

\section{References}

1. Allen, F.; Carletti, E. An overview of the crisis: Causes, consequences, and solutions. Int. Rev. Financ. 2010, 10, 1-26.

2. Kenny, G.; Morgan, J. Some Lessons from the Financial Crisis for the Economic Analysis; ECB Occasional Paper No. 130; European Central Bank (ECB): Frankfurt, Germany, 2011.

3. International Monetary Fund (IMF). Global Financial Stability Report-Responding to the Financial Crisis and Measuring Systemic Risks. International Monetary Fund: Washington, DC, USA, 2009.

4. Hatzius, J.; Hooper, P.; Mishkin, F.S.; Schoenholtz, K.L.; Watson, M.W. Financial Conditions Indexes: A Fresh Look after the Financial Crisis; NBER Working Paper No. 16150; National Bureau of Economic Research (NBER): Cambridge, MA, USA, 2010. 
5. Brave, S.; Butters, R.A. Monitoring financial stability: A financial conditions index approach. Econ. Perspect. 2011, 35, 22-43.

6. Hakkio, C.S.; Keeton, W.R. Financial stress: What is it, how can it be measured, and why does it matter? Econ. Rev. 2009, 94, 5-50.

7. Carlson, M.; Lewis, K.; Nelson, W. Using Policy Intervention to Identify Financial Stress; Federal Reserve Board Working Paper No. 2012-02; Federal Reserve: Washington, DC, USA, 2012.

8. Holló, D.; Kremer, M.; Lo Duca, M. CISS - A Composite Indicator of Systemic Stress in the Financial System; European Central Bank Working Paper No. 1426; European Central Bank (ECB): Frankfurt, Germany, 2012.

9. Kliesen, K.L.; Smith, D.C. Measuring Financial Market Stress; Federal Reserve Bank of St. Louis Economic Synopses No. 2; Federal Reserve Bank of St. Louis: St. Louis, MO, USA, 2010.

10. Oet, M.V.; Eiben, R.; Bianco, T.; Gramlich, D.; Ong, S.J. The Financial Stress Index: Identification of Systemic Risk Conditions; Federal Reserve Bank of Cleveland Working Paper No. 11/30; Federal Reserve Bank of Cleveland: Cleveland, OH, USA, 2011.

11. Lo Duca, M.; Peltonen, T.A. Assessing systemic risks and predicting systemic events. J. Bank. Financ. 2013, 37, 2183-2195.

12. Korinek, A. Systemic Risk-Taking: Amplification Effects, Externalities, and Regulatory Responses. Networks Financial Institute Working Paper No. 2011-WP-13; Networks Financial Institute: Terre Haute, IN, USA, 2011.

13. Borio, C.; Lowe, P. Assessing the risk of banking crises. BIS Q. Rev. 2002, December, 43-54.

14. Rosenberg, M. Financial Conditions Watch, Global Financial Market Trends and Policy. Bloomberg LLP. Available online: http://www.ssc.wisc.edu/ mchinn/fcw_sep112009.pdf. (accessed on 1 July 2015).

15. Thakor, A.V. Book review "Comparing Financial Systems". Rev. Financ. Stud. 2001, 14, 577-581.

16. Merton, R.C.; Bodie, Z. A conceptual framework for analyzing the financial environment. In The Global Financial System: A Functional Perspective; Crane, D.B., Ed.; Harvard Business School Press: Boston, MA, USA, 1995; pp. 3-31.

17. Simon, H. Architecture of complexity. Proc. Am. Philos. Soc. 1962, 106, 467-482.

18. Allen, F.; Gale, D. Comparing Financial Systems; MIT Press: Cambridge, MA, USA, 2000.

19. Song, F.; Thakor, A.V. Financial system architecture and the co-evolution of banks and capital markets. Econ. J. 2010, 120, 1021-1055.

20. Thakor, A.V. The design of financial systems: An overview. J. Bank. Financ. 1996, 20, 917-948.

21. Oet, M.V.; Dooley, J.; Gramlich, D.; Sarlin, P.; Ong, S. Evaluating the Information Value for Measures of Systemic Conditions; Federal Reserve Bank of Cleveland Working Paper: Cleveland, OH, USA, 2015.

22. Siddiqi, N. Credit Risk Scorecards: Developing and Implementing Intelligent Credit Scoring; SAS Institute: Cary, NC, USA, 2005; pp. 79-83.

23. Patel, S.; Sarkar, A. Crises in developed and emerging stock markets. Financ. Anal. J. 1998, 54, $50-61$.

24. SIFMA Statistics Website. Available online: http://www.sifma.org/research/statistics.aspx (accessed on 7 July 2015) 
25. Estrella, A.; Trubin, M. The Yield Curve as a Leading Indicator: Some Practical Issues; Current Issues in Economics and Finance: New York, NY, USA, 2006; Volume 12.

26. Haubrich, J. Does the Yield Curve Signal Recession? Federal Reserve Bank of Cleveland: Cleveland, OH, USA, 2006.

27. Bordo, M.D.; Dueker, M.; Wheelock, D. Aggregate Price Shocks and Financial Instability: An Historical Analysis; Federal Reserve Bank of St. Louis Working Paper 2000-005B; Federal Reserve Bank of St. Louis: St. Louis, MO, USA, 2000.

28. Illing, M.; Liu, Y. An Index of Financial Stress for Canada; Working Paper 2003-14; Bank of Canada: Ottawa, ON, Canada.

29. Illing, M.; Liu, Y. Measuring financial stress in a developed country: An application to Canada. J. Financ. Stab. 2006, 2, 243-265.

30. Gramlich, D.; Bianco, T.; Oet, M.V. Weighting Methods for Financial Stress Indices-Comparison and Implications for Risk Management. J. Financ. Manag. Anal. 2012, 25, 1-13.

31. FFIEC Website. Available online: http://www.ffiec.gov/E16.htm (accessed on 5 July 2015)

32. Gramlich, D.; Miller, G.; Oet, M.; Ong, S. Early Warning Systems for Systemic Banking Risk: Critical Review and Modeling Implications. Bank. Bank Syst. 2010, 5, 199-211.

33. Demirgüç-Kunt, A.; Detragiache, E. Cross-Country Empirical Studies of Systemic Bank Distress: A Survey; IMF Working Paper No. 96/05; International Monetary Fund (IMF): Washington, DC, USA, 2005.

34. Reinhart, C.; Rogoff, K. This Time is Different: A Panoramic View of Eight Centuries of Financial Crises; NBER Working Paper, No. 13882; National Bureau of Economic Research (NBER): Cambridge, MA, USA, 2008.

35. Somers, R.H. A new asymmetric measure of association for ordinal variables. Am. Sociol. Rev. 1962, 27, 799-811.

36. Miron, J.A. Financial panics, the seasonality of the nominal interest rate, and the founding of the Fed. Am. Econ. Rev. 1986, 76, 125-140.

37. Freixas, X.; Rochet, J.-C. Microeconomics of Banking, 2nd ed.; MIT Press: Cambridge, MA, USA, 2008.

38. Kaminsky, G.L.; Reinhart, C.M. The twin crises: The causes of banking and balance-of-payments problems. Am. Econ. Rev. 1999, 89, 473-500.

39. Caprio, G.; Klingebiel, D. Bank Insolvencies: Cross Country Experiences; World Bank Policy Research Working Paper No. 1620; World Bank; DC, USA, 1996.

40. Bai, J.; Perron, P. Estimating and testing linear models with multiple structural changes. Econometrica 1998, 66, 47-78.

41. Mishkin, F.S. Understanding Financial Crises: A Developing Country Perspective; NBER Working Paper Series, No. w5600; National Bureau of Economic Research (NBER): Cambridge, MA, USA, 1997.

42. McKinnon, R.I.; Pill, H. Credible liberalizations and international capital flows: The “overborrowing syndrome”. Financ. Deregul. Integr. East Asia NBER-EASE, 1996, 5, 7-50.

43. Sachs, J.; Tornell, A.; Velasco, A. Financial crises in emerging markets: The lessons from 1995. Brook. Pap. Econ. Act. 1996, 147-215. 
44. Weller, C. Financial crises after financial liberalization: Exceptional circumstances or structural weakness? J. Dev. Stud. 2001, 38, 98-127.

45. Fama, E.F.; French, K.R. Business conditions and expected returns on stocks and bonds. J. Financ. Econ. 1989, 25, 23-49.

46. Schwert, W. Why does stock volatility change over time? J. Financ. 1989, 44, 1115-1153.

47. Shiller, R.J. Stock Market Volatility; MIT Press: Cambridge, MA, USA, 1989.

48. FDIC Website. Available online: https://www2.fdic.gov/hsob/SelectRpt.asp?EntryTyp=30 (accessed on 5 July 2015)

(C) 2015 by the authors; licensee MDPI, Basel, Switzerland. This article is an open access article distributed under the terms and conditions of the Creative Commons Attribution license (http://creativecommons.org/licenses/by/4.0/). 